Article

\title{
Nitrogen Fertilization of Plants Irrigated with Desalinated Water: A Study of Interactions of Nitrogen with Chloride
}

\author{
Asher Bar-Tal ${ }^{1, *}$, Escain Kiwonde ${ }^{1,2}$, Beeri Kanner ${ }^{1,2}$, Ido Nitsan ${ }^{1}$, Raneen Shawahna ${ }^{1}$ and \\ Daniel Kurtzman 1 \\ 1 Institute of Soil, Water and Environmental Sciences, Agricultural Research Organization (ARO), \\ The Volcani Center, Rishon Lezion 75359, Israel; escain.kiwonde@mail.huji.ac.il (E.K.); \\ beeri.kanner@gmail.com (B.K.); idon@volcani.agri.gov.il (I.N.); raneen@volcani.agri.gov.il (R.S.); \\ daniel@volcani.agri.gov.il (D.K.) \\ 2 The Robert H. Smith Faculty of Food Agriculture and Environment, The Hebrew University of Jerusalem, \\ Rehovot 76100001, Israel \\ * Correspondence: abartal@volcani.agri.gov.il; Tel.:+97-25-06220310
}

Received: 22 June 2020; Accepted: 17 August 2020; Published: 21 August 2020

\begin{abstract}
The overall aim of this research was to optimize nitrogen $(\mathrm{N})$ fertilization of plants under desalinated water and a wide range of chloride concentrations for high yield while minimizing downward leaching of nitrate and chloride. The response of two crops, lettuce and potato, to $\mathrm{N}$ concentration $\left(\mathrm{C}_{\mathrm{N}}\right)$ in the irrigating solution using desalinated and wide range of $\mathrm{Cl}$ concentrations $\left(C_{C L}\right)$ was evaluated. The yields of both crops increased with $\mathrm{N}$ up to optimal $\mathrm{C}_{\mathrm{N}}$ of the irrigating solution and decreased as $\mathrm{C}_{\mathrm{CL}}$ increased. Optimal $\mathrm{C}_{\mathrm{N}}$ in both crops was higher in the desalinated water than high $\mathrm{C}_{\mathrm{CL}}$ treatments. $\mathrm{N}$ uptake by plants increased with $\mathrm{C}_{\mathrm{N}}$ in the irrigating solution and the highest uptake was at low $\mathrm{C}_{\mathrm{CL}}$. As expected, $\mathrm{N}$ fertilization suppressed $\mathrm{Cl}$ accumulation in plant tissues. Drainage of $\mathrm{N}$ and $\mathrm{Cl}$ increased with increase in $\mathrm{C}_{\mathrm{CL}}$ in the irrigating solution and $\mathrm{N}$ fertilization above optimal $\mathrm{C}_{\mathrm{N}}$ resulted in steep rise in downward $\mathrm{N}$ leaching. The overall conclusion is that as water quality is improved through desalination, higher $\mathrm{N}$ supply is required for high yields with less groundwater pollution by downward leaching of $\mathrm{N}$ and $\mathrm{Cl}$.
\end{abstract}

Keywords: fertilization; leachate; lettuce; lysimeter; nitrate; potato; salinity

\section{Introduction}

The growing demand for fresh water led to an increase in the production of desalinated water, mainly in arid and semiarid regions [1,2]. An annual production of $585 \times 10^{6} \mathrm{~m}^{3} /$ year in Israel was reported [3], approximately $40 \%$ of the total fresh water consumption [4]. The use of desalinated seawater for irrigation in Israel was estimated at $200 \times 10^{6} \mathrm{~m}^{3} /$ year [5], which is $\sim 40 \%$ of the national freshwater irrigation consumption.

In intensive agriculture, the majority of crops grown are defined as glycophyte plants, meaning high sensitivity to salinity above a threshold value, which is specific for each crop [6-9]. Salinity may interfere with mineral nutrition acquisition by plants in two ways [10,11]: (i) the total ionic strength of the soil solution, regardless of its composition, can reduce nutrient uptake and translocation, and (ii) uptake competition with specific ions such as sodium and chloride can reduce nutrient uptake. These interactions may lead to Na-induced $\mathrm{Ca}$ and/or $\mathrm{K}$ deficiencies [12] and $\mathrm{Cl}^{-}$induced inhibition of $\mathrm{NO}_{3}{ }^{-}$uptake $[13,14]$. Antagonism between $\mathrm{Cl}^{-}$and $\mathrm{NO}_{3}{ }^{-}$uptake by plants was demonstrated in numerous publications [13]. This antagonism was found in various plants, including substrate-grown crops such as melon and lettuce [15], tomato and melon [16-18], and rose [14]. Direct competition 
between $\mathrm{NO}_{3}{ }^{-}$and $\mathrm{Cl}^{-}$on uptake by plants was reported in several publications [19-21]. Therefore, there is a possibility that yield reduction due to increased salinity may be partially due to induced deficiency of $\mathrm{N}$ by the increased external $\mathrm{Cl}$ concentration. Addition of nitrate to the irrigation water reduced chloride accumulation in avocado plant and alleviated its adverse effects [22], whereas another publication suggested that a reduction in water uptake led to the reduced nitrate uptake [23]. Under conditions of salinity, nitrogen concentration in plant leaves decreased due to increasing chloride concentration in pepper [24], tomato [16], lettuce, and Chinese cabbage [25].

Due to the above findings, increasing the $\mathrm{NO}_{3}{ }^{-}$supply to sensitive crops irrigated with water containing high chloride concentrations was recommended in several publications $[13,16,22]$. Consequently, the shift from irrigation with conventional water to using desalinated water calls for adjustment in the amount of additional minerals. Adjustment in the amount of minerals needed for plant growth requires understanding the effects of the quality of water supplied for irrigation on plants response to nutrients.

Irrigation with desalinated water was found to increase maximum yields of bell peppers by $50 \%$ and allowed a reduction in irrigation water application rate by half compared to irrigation with local brackish groundwater (electrical conductivity $\left(E C=3.2 \mathrm{dS} \cdot \mathrm{m}^{-1}\right)$ [26]. It was shown that the higher water dose required with saline water than with desalinated water was due to the required excess water for leaching out soluble salts from the root zone [26]. This leaching application results in high volumes of drainage water that are often enriched with salts and also in other nutrients [27] including nitrate [28]. The reduction in the required leaching fraction with the reduction in water salinity was shown to reduce $\mathrm{N}$ leaching and enhance the efficiency of $\mathrm{N}$ fertilization [29]. A simulation study of water and salts transport in soil of irrigated orchard in Mediterranean region showed that a shift from natural water to desalinated seawater reduced downward leaching of contaminants to the groundwater [5].

Contamination of groundwater by nitrate is a major problem worldwide [30-32]. In Israel, it has led to disqualification of a greater number of drinking water wells than any other environmental contaminant in the beginning of the 21st century [33]. Nitrate is highly soluble and in most soils it is very mobile within the soil-water solution. Consequently, when nitrogen fertilizer inputs exceed the amount of nitrogen needed by the plant, the excess nitrate is then easily leached by irrigation water and rainwater to deeper soil layers, finally reaching groundwater [34,35].

We hypothesized that optimal nitrogen concentration for the highest yield will be lower and the total uptake of water and nitrogen will increase with decrease in the chloride concentration of the irrigating solution; consequently, chloride and nitrate downward leaching below the root zone will decrease with reducing salinity of the irrigation water. Optimization of $\mathrm{N}$ application in combination with irrigation with desalinated water will also lead to reduction of $\mathrm{N}$ and $\mathrm{Cl}$ fluxes below the root zone and protect underground water sources from $\mathrm{N}$ and $\mathrm{Cl}$ contamination.

The overall aim of this research was to optimize nitrogen fertilization of plants under desalinated water and a wide range of chloride concentrations for high yield while minimizing downward leaching of nitrate and chloride. The specific objectives were (1) to determine the response curves of lettuce biomass and potato tubers to $C_{N}\left(N\right.$ concentration in the irrigating solution) at different $C_{C l}$ ( $\mathrm{Cl}$ concentration in the irrigating solution); (2) to explore the effects of $\mathrm{C}_{\mathrm{N}}$ at different $\mathrm{C}_{\mathrm{Cl}}$ values on $\mathrm{N}$ and $\mathrm{Cl}$ concentrations in the leaves of lettuce and potato; and (3) to determine the effects of $\mathrm{N}$ and $\mathrm{Cl}$ concentrations in the irrigating water on the water leaching fraction (LF) and the downward leaching of nitrogen and chloride.

\section{Materials and Methods}

The effect of $\mathrm{N}$ concentrations combined with irrigation with desalinated water and a wide range of $\mathrm{Cl}$ concentrations on lettuce and potato plants was investigated in five experiments: Three winter season potato (Solanum tuberosum L.) experiments (20 January-3 May 2016, 15 January-17 May 2017, and 1 March-27 June 2018) and two summer season lettuce (Lactuca sativa L.) experiments (17 August 
2016-26 September 2016 and 14 September-22 October 2017). The following varieties were used for the three potato experiments; Sifra, Rozana, and Desire in 2016, 2017, and 2018. The variety Romit-Raviv was used for the two lettuce experiments. The experiments were carried out in automated lysimeters at Bet Dagan, Israel ( $\left.34^{\circ} 49^{\prime} 15^{\prime \prime} \mathrm{E}, 31^{\circ} 59^{\prime} 34^{\prime \prime} \mathrm{N}\right)$.

\subsection{Description of the Study Site and Lysimeter System}

Ninety-six lysimeters of $60 \mathrm{~L}$ volume (height: $54 \mathrm{~cm}$; radius in the range of 55 to $60 \mathrm{~cm}$, from bottom to top) were placed on 24 tables. The lysimeters were filled with coarse sand ( $>1400 \mu \mathrm{m}-13.8 \%$, 1000-1400 $\mu \mathrm{m}-56.5 \%, 500-1000 \mu \mathrm{m}-25 \%, 250-500 \mu \mathrm{m}-1.8 \%, 50-250 \mu \mathrm{m}-2.2 \%$, and $<50-0.6 \%$ ), and the following physical properties; bulk density: $1.66 \mathrm{~g} \mathrm{~cm}^{-3}$, total porosity: $37.4 \%$, and saturated hydraulic conductivity: $3.3 \mathrm{~cm} \mathrm{~min}^{-1}$. The sand in the lysimeters was used throughout the five experiments with no replacement and/or washing of the medium before starting each experiment. A $60 \mathrm{~cm}$ long rockwool drain with a diameter of $5 \mathrm{~cm}$ was installed in each lysimeter. The dimensions of the rockwool drain were made according to Ben-Gal and Shani (2002) [36] for preventing saturation at the bottom of the lysimeters and to allow continuous water flow. Below each drain was a container for the collection of the drainage (96 drainage containers) and the weight of the drainage was determined manually every few days. The irrigation was done by nutrient solutions from 24 solution tanks (one for each treatment) each with $200 \mathrm{~L}$ capacity. The solution tanks were supplied with desalinated water from two storage tanks with a total volume of $5 \mathrm{~m}^{3}$. The desalinated water was produced by a desalination

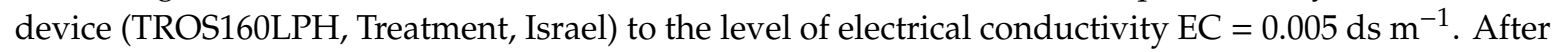
the 24 tanks were filled with water, salts and fertilizers that were weighed in the laboratory were added to each container according to treatments. Each solution container had a shipping pump and 4 tubes connected to 4 lysimeters for different repetitions of the same treatment. Each container irrigated 4 lysimeters in sequence using a separate valve for each lysimeter. The entire irrigation system was controlled by a computer using a tailored control software (Crystal Vision, Kibbutz Samar, Israel).

\subsection{Experiments Treatments}

The two lettuce experiments consisted of 24 treatments of full factorial combinations of $6 \mathrm{~N}$ and 4 $\mathrm{Cl}$ concentrations (Table 1). The first potato experiment in 2016 included 24 treatments consisted of $6 \mathrm{~N}$ and $4 \mathrm{Cl}$ concentrations, the second potato experiment in 2017 included 16 treatments consisted of $4 \mathrm{~N}$ and $4 \mathrm{Cl}$ concentrations, and the third potato experiment consisted of 20 treatments consisted of $4 \mathrm{~N}$ and $5 \mathrm{Cl}$ concentrations.

Table 1. List of the Lettuce and potato experiments conducted in the lysimeters, Bet Dagan, 2016-2018.

\begin{tabular}{cccccc}
\hline Crop & Potato & Lettuce & Potato & Lettuce & Potato \\
\hline Planting & 15.1 .2016 & 17.8 .2016 & 15.1 .2017 & 14.9 .2017 & 1.3 .2018 \\
\hline Harvest & 31.5 .2016 & 27.9 .2016 & 17.5 .2017 & 22.10 .2017 & 27.6 .2018 \\
\hline $\mathrm{Cl}\left(\mathrm{mg} \mathrm{L}^{-1}\right)$ & $15,150,350,700$ & $15,150,350,700$ & $15,150,350,700$ & $15,150,350,700$ & $\begin{array}{c}15,200,600, \\
1100,1500\end{array}$ \\
\hline $\mathrm{N}\left(\mathrm{mg} \mathrm{L}^{-1}\right)$ & $\begin{array}{c}10,20,30,40, \\
60,80\end{array}$ & $\begin{array}{c}25,50,75,100, \\
125,140\end{array}$ & $10,50,100,150$ & $\begin{array}{c}225,45,65,85, \\
100,1255\end{array}$ & $10,50,100,150$ \\
\hline
\end{tabular}

\subsection{Measurements Performed}

\subsubsection{Plant Growth and Yield}

In the lettuce experiment, the heads' (leaves) fresh and dry weights (FW and DW, respectively) were determined. Lettuce roots FW and DW were also recorded. At the termination of the potato experiments, the above ground part of all plants from all lysimeters were cut and separated from tubers and the FW and DW of the above ground part and tubers were determined separately. In all 
experiments, the fresh samples of the plants organs were rinsed for $15 \mathrm{~s}$ with deionized water, dried at $70^{\circ} \mathrm{C}$ in a ventilated oven, and weighed again in order to determine dry matter content.

Quadratic equation was used for quantitative expression of the potato tubers yield as a function of $\mathrm{C}_{\mathrm{N}}$ at each $\mathrm{C}_{\mathrm{Cl}}$ value,

$$
\mathrm{Y}=\mathrm{a} \mathrm{X}^{2}+\mathrm{b} \mathrm{X}+\mathrm{c}
$$

where $y$ is the yield; $x$ is the nutrient concentration $\left(C_{N}\right)$; and $a, b$, and $c$ are coefficients derived by best fitting.

Mitcherlich model Equation (2) was used for quantitative expression of the potato tubers yield as function of $\mathrm{C}_{\mathrm{N}}$ at each $\mathrm{C}_{\mathrm{Cl}}$ value,

$$
\mathrm{y}=\mathrm{A}\left(1-\mathrm{e}^{-\mathrm{Cx}}\right)
$$

where $y$ is the yield, $x$ is the nutrient concentration $\left(C_{N}\right)$, $A$ is the potential yield that would be obtained by supplying all growth factors in their optimum amounts, and $\mathrm{C}$ is a proportionality constant that depends on the individual growth factor.

\subsubsection{Mineral Concentration in Plant Tissues}

After harvesting and oven drying, the subsamples of the plant organs were ground to a fine powder. A subsample $(100 \mathrm{mg})$ in powder form was digested using sulfuric acid and peroxide according to Snell and Snell (1948). N was determined in an autoanalyzer (Discrete Autoanalyzer Gallery, Thermo Fisher Scientific, Finland). Chloride was extracted from the leaf powder in water (100:1 water/dry matter) and determined with a $\mathrm{Cl}$ analyzer (Sherwood-Scientific, chloride analyzer 926, Cambridge, UK).

\subsubsection{Mineral Concentration in Drainage}

Drainage water was collected continuously under each lysimeter and the accumulated leachate was weighed frequently, every 3 to 7 days and subsamples of water were taken for analyses of ammonium, nitrate, and chloride concentrations in each event of drainage collection (5 to 15 times) using the autoanalyzer described above.

\subsubsection{Leaching Fraction and Leached $\mathrm{N}$ and $\mathrm{Cl}$}

As stated before, drainage water was collected continuously and weighed periodically for calculations of the drainage volume, leaching fraction (LF), and the total amount of $\mathrm{N}$ and $\mathrm{Cl}$ in the drainage $\left(\mathrm{M}_{\mathrm{N}}\right.$ and $\mathrm{M}_{\mathrm{Cl}}$, respectively). LF was calculated as the ratio of the amount of water collected as drainage to the amount of irrigated water. A $25 \%$ given as LF was maintained in one of the treatments with high nitrogen and low chloride. The irrigation dose in all other treatments was the same as in the reference treatment. $\mathrm{M}_{\mathrm{N}}$ and $\mathrm{M}_{\mathrm{Cl}}$ were calculated in each measurement event by multiplication of the volume of the drainage by the concentration of $\mathrm{N}$ (sum of $\mathrm{NH}_{4}{ }^{-}-\mathrm{N}$ and $\mathrm{NO}_{3}{ }^{-}-\mathrm{N}$ ) or $\mathrm{Cl}$, respectively, and then the total $\mathrm{M}_{\mathrm{N}}$ and $\mathrm{M}_{\mathrm{Cl}}$ were calculated as sum of all the measured events. The average $\mathrm{N}$ and $\mathrm{Cl}$ concentrations in the drainage were calculated by dividing the total $\mathrm{M}_{\mathrm{N}}$ and $\mathrm{M}_{\mathrm{Cl}}$ by the accumulated drainage volume.

\subsection{Statistics}

The main effects of the $\mathrm{N}$ and $\mathrm{Cl}$ concentrations and their interactions on measured variables were determined statistically using the two-way ANOVA procedure of JMP 14. The significance of comparisons among treatments was tested by the Tukey-Kramer honestly significant difference (HSD) at $p<0.05$. Response curves of plant biomass production to $\mathrm{C}_{\mathrm{N}}$ and $\mathrm{N}$ concentration and mass in the drainage water as function of $C_{N}$ were fit using the NLIN procedure of JMP 14. 


\section{Results}

\subsection{Plants Response to $\mathrm{N}$ and $\mathrm{Cl}$ Concentrations}

For achieving the first objective, to determine the response curves of lettuce biomass and potato tubers to $\mathrm{C}_{\mathrm{N}}$ at different $\mathrm{C}_{\mathrm{Cl}}$, the biomass production of lettuce and the yield of potato were determined in the above described lettuce and potato experiments.

\subsubsection{Biomass in Lettuce Experiments}

In the two lettuce experiments, the lettuce head fresh and dry weight were significantly affected by $\mathrm{C}_{\mathrm{N}}$ and $\mathrm{C}_{\mathrm{CL}}$, but no significant interaction between these factors was obtained (Table 2). As expected, lettuce head dry weight increased significantly as $C_{N}$ was raised from the lowest value of $25 \mathrm{mg} \mathrm{L}^{-1}$ to 50 and $45 \mathrm{mg} \mathrm{L}^{-1}$ in the first and second experiments, respectively. The highest head weights were obtained with 75 and $65 \mathrm{mg} \mathrm{L}^{-1}$ in the first and second experiments. As expected, increasing $\mathrm{C}_{\mathrm{Cl}}$ had negative effect on lettuce head fresh and dry weights in both experiments. In the first experiment, a significant reduction in the FW and DW was obtained with the increase from 150 to $350 \mathrm{mg} \mathrm{L}^{-1}$, and 15 to $350 \mathrm{mg} \mathrm{L}^{-1}$, whereas in the second experiment significant lower FW and DW were obtained as the $\mathrm{C}_{\mathrm{Cl}}$ was raised to $700 \mathrm{mg} \mathrm{L}^{-1}$.

Table 2. The effect of $C_{N}$ and $C_{C L}$ on lettuce head fresh and dry weight and root fresh weight. Probability of $F$ values for $\mathrm{C}_{\mathrm{N}}, \mathrm{C}_{\mathrm{Cl}}$, Block factors, and the interaction of $\mathrm{C}_{\mathrm{N}}$ and $\mathrm{C}_{\mathrm{Cl}}$ were determined using the two-way ANOVA procedure of JMP 14. Different letters on the right side of values indicate significant difference between treatments (HSD) at $p<0.05$ by the Tukey-Kramer honestly test. No letters are presented when no significant difference was obtained.

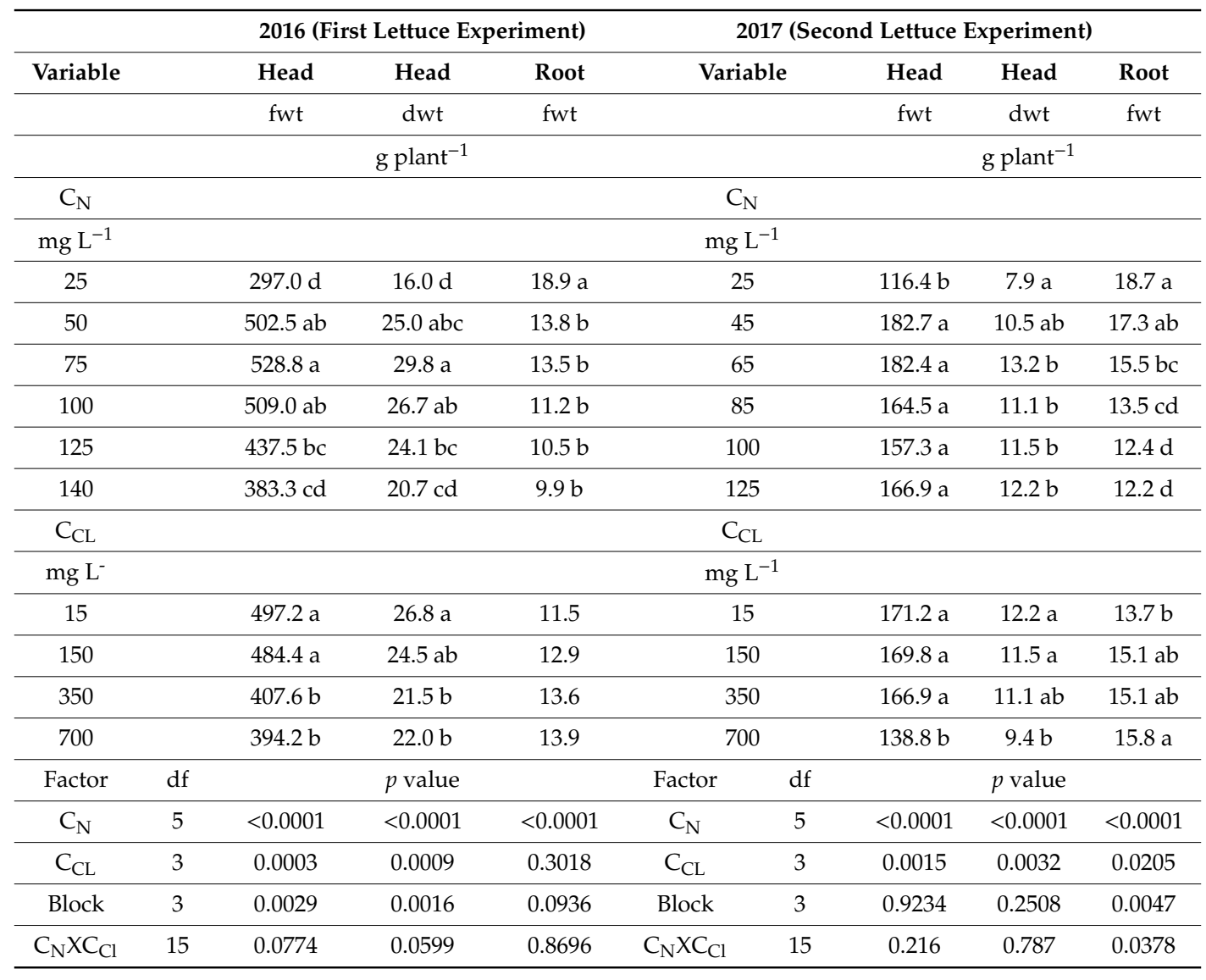

When the response of the head dry weight as a function of $C_{N}$ for each $C_{C L}$ level in the first experiment is presented, the same trend is obtained, except the desalinated water $\left(\mathrm{C}_{\mathrm{Cl}}=15 \mathrm{mg} \mathrm{L}{ }^{-1}\right)$ 
treatment in which the maximum weight occurred with the maximal $\mathrm{C}_{\mathrm{N}}, 125 \mathrm{mg} \mathrm{L}^{-1}$ (Figure 1). Equation (1) was employed to fit curves to the response of the lettuce head to $C_{N}$ at each $C_{C l}$ value in the two lettuce experiments (Figure 1). In the first experiment, the $\mathrm{r}^{2}$ at the different $\mathrm{C}_{\mathrm{Cl}}$ was in the range of 0.58 to 0.94 (Table 3). The obtained optimum $\mathrm{C}_{\mathrm{N}}$ of the desalinated water $\left(\mathrm{C}_{\mathrm{Cl}}=15 \mathrm{mg} \mathrm{L}^{-1}\right)$ was $94.6 \mathrm{mg} \mathrm{L}^{-1}$ and for water with higher $\mathrm{C}_{\mathrm{Cl}}, 150,350$, and $700 \mathrm{mg} \mathrm{L}^{-1}$, the optimum $\mathrm{C}_{\mathrm{N}}$ values were $84.3,80.8$, and $90.8 \mathrm{mg} \mathrm{L}^{-1}$, respectively. In the second experiment, the $\mathrm{r}^{2}$ at the different $\mathrm{C}_{\mathrm{Cl}}$ were in the range of 0.60 to 0.91 for $C_{C L} 15$ to $350 \mathrm{mg} \mathrm{L}^{-1}$ (Table 3). The relative effect of $C_{N}$ on the head $D W$ at $700 \mathrm{mg} \mathrm{Cl}^{-1}$ was much smaller than at the lower $\mathrm{C}_{\mathrm{Cl}}$ values (Figure 1 ) with low $\mathrm{r}^{2}$ just 0.39 (Table 3 ). The obtained optimum $\mathrm{C}_{\mathrm{N}}$ of the desalinated water $\left(\mathrm{C}_{\mathrm{Cl}}=15 \mathrm{mg} \mathrm{L}^{-1}\right)$ was $129.8 \mathrm{mg} \mathrm{L}^{-1}$, compared with $87.8,88.9$, and $124.0 \mathrm{mg} \mathrm{L}^{-1}$, at $\mathrm{C}_{\mathrm{Cl}}$ treatments of 150,350 , and $700 \mathrm{mg} \mathrm{L}^{-1}$, respectively. In both experiments, the highest calculated optimal $C_{N}$ values for lettuce were obtained with desalinated water. In both experiments the lowest optimal $C_{N}$ values were obtained at the median $C_{C L}$ levels of 150 and $350 \mathrm{mg} \mathrm{L}^{-1}$.

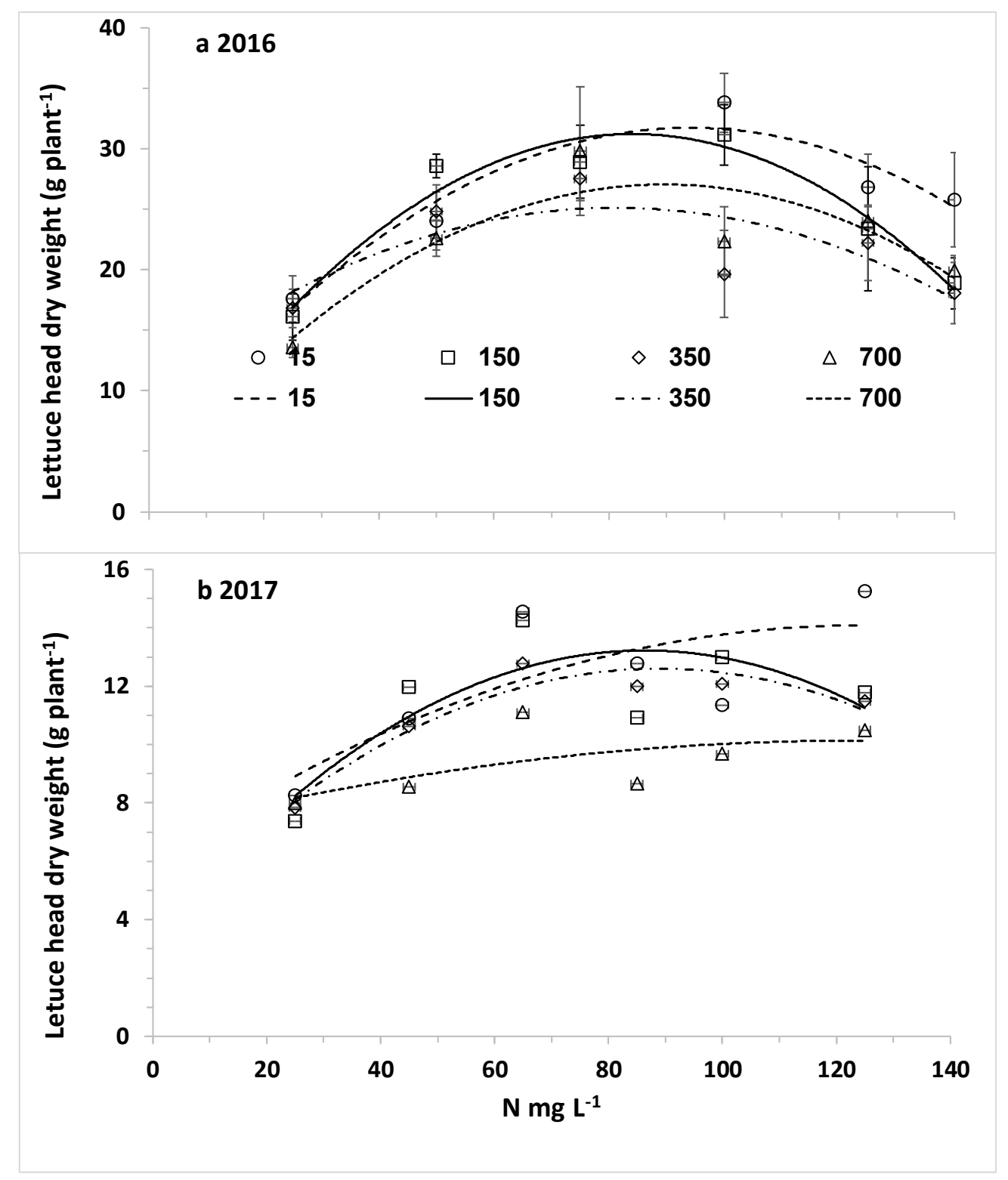

Figure 1. Lettuce head dry weight as a function of $\mathrm{N}$ concentration in the irrigating solution at different $\mathrm{Cl}$ concentrations in the irrigating solution (a) first experiment on 26 September 2016 and (b) second experiment on 22 October 2017. 
Table 3. Best fit parameters of Equation (1) for best fit curves of Figure 1. $r^{2}$ —coefficient of determination.

\begin{tabular}{|c|c|c|c|c|c|}
\hline $\mathrm{Cl}$ & $\mathbf{a}$ & $\mathbf{b}$ & c & $\mathbf{r}^{2}$ & N Optimum \\
\hline $\mathrm{mg} \mathrm{L}^{-1}$ & & \multicolumn{3}{|c|}{$\mathrm{mg} \mathrm{L}^{-1}$} & $\mathrm{mg} \mathrm{L}^{-1}$ \\
\hline \multicolumn{6}{|c|}{2016} \\
\hline 15 & -0.0031 & 0.5865 & 4.1 & 0.91 & 94.6 \\
\hline 150 & -0.0041 & 0.6914 & 2.2 & 0.94 & 84.3 \\
\hline 350 & -0.0022 & 0.3557 & 10.7 & 0.58 & 80.8 \\
\hline 700 & -0.003 & 0.5447 & 2.6 & 0.77 & 90.8 \\
\hline \multicolumn{6}{|c|}{2017} \\
\hline 15 & -0.0005 & 0.1298 & 6.00 & 0.60 & 129.8 \\
\hline 150 & -0.0013 & 0.2284 & 3.36 & 0.63 & 87.85 \\
\hline 350 & -0.0011 & 0.1957 & 3.89 & 0.91 & 88.95 \\
\hline 700 & -0.0002 & 0.0496 & 7.05 & 0.39 & 124.0 \\
\hline
\end{tabular}

In both lettuce experiments, the root fresh weight was much smaller than the head (Table 2); the shoot to root ratio was in the range of 45.9 to 15.7 in the first experiment and 13.7 to 6.2 in the second experiment. In both experiments, the root fresh weight was affected significantly by $C_{N}$. In both experiments, the highest root FW were obtained at the lowest $C_{N}$ of $25 \mathrm{mg} \mathrm{L}^{-1}$ and decreased insignificantly with further increase in $C_{N}$ from 50 and $65 \mathrm{mg} \mathrm{l}^{-1}$ in the first and second experiments, respectively (Table 2). In the first experiment, the root fresh weight was not affected by $\mathrm{C}_{\mathrm{Cl}}$ and no significant interaction of $C_{N}$ with $C_{C l}$ was obtained, whereas in the second experiment it was significantly increased as the $\mathrm{C}_{\mathrm{Cl}}$ increased in the studied range of 15 to $700 \mathrm{mg} \mathrm{L}^{-1}$. A significant interaction effect of $\mathrm{C}_{\mathrm{N}}$ with $\mathrm{C}_{\mathrm{Cl}}$ on the root $\mathrm{FW}$ was obtained in the second experiment (Table 2), but no change in the trend of the effect of $\mathrm{C}_{\mathrm{N}}$ at different $\mathrm{C}_{\mathrm{Cl}}$ was obtained.

\subsubsection{Biomass in Potato Experiments}

Potato biomass, tubers fresh and dry weight, and shoot dry weight responded positively to $C_{N}$ in the three potato experiments (Table 4). In the first experiment, significant increases in the tuber and shoot mass were obtained with each increment of raising $C_{N}$ by 10 or $20 \mathrm{mg} \mathrm{L}^{-1}$ with the highest masses at $80 \mathrm{mg} \mathrm{L}^{-1}$. In the second and third experiments, the range of $C_{\mathrm{N}}$ was extended to $150 \mathrm{mg} \mathrm{L}^{-1}$. In the second experiment, the highest shoot and tuber masses were obtained at $100 \mathrm{mg} \mathrm{N} \mathrm{L}^{-1}$ and they decreased with a further raise of $C_{N}$ to $150 \mathrm{mg} \mathrm{L}^{-1}$. In the third experiment, the highest shoot and tuber masses were obtained at $150 \mathrm{mg} \mathrm{N} \mathrm{L}^{-1}$, but the difference between the mass at $\mathrm{C}_{\mathrm{N}} 100$ and $150 \mathrm{mg} \mathrm{L}^{-1}$ were insignificant. In the first and second experiments, the effect of $\mathrm{C}_{\mathrm{Cl}}$ on the potato plants was tested in the range of 15 to $700 \mathrm{mg} \mathrm{L}^{-1}$. In the first experiment, the increase of $C_{C L}$ in this range had negative effect on potato shoot and tubers masses, as expected; however, in the second experiment the effects on the shoot and tubers mass were insignificant. Therefore, in the third experiment the range of $\mathrm{C}_{\mathrm{CL}}$ was extended to $1500 \mathrm{mg} \mathrm{L}^{-1}$ resulting in a significant negative effect on the shoot dry mass and the tubers fresh and dry mass. Significant interaction of the effects of $C_{N}$ with $C_{C L}$ was obtained just for the shoot and tubers dry weights in the first experiment and shoot dry weight and tubers fresh weight in the third experiment. The significant interactions between $\mathrm{C}_{\mathrm{N}}$ and $\mathrm{C}_{\mathrm{Cl}}$ in the first and third experiments are due to differences in the magnitudes of the effect of $C_{N}$ on the tubers mass at different $C_{C l}$ values, whereas the general trend is similar, as shown for the tubers fresh weight in Figure 2. 
Table 4. The effect of $\mathrm{C}_{\mathrm{N}}$ and $\mathrm{C}_{\mathrm{CL}}$ on potato shoot dry weight and tubers fresh and dry weight and $\mathrm{N}, \mathrm{Cl}$, and nitrate-N concentrations in leaf tissue. Probability of $F$ values for $\mathrm{C}_{\mathrm{N}}, \mathrm{C}_{\mathrm{Cl}}$, Block factors, and the interaction of $\mathrm{C}_{\mathrm{N}}$ and $\mathrm{C}_{\mathrm{Cl}}$ were determined using the two-way ANOVA procedure of JMP 14. Different letters on the right side of values indicate significant difference between treatments (HSD) at $p<0.05$ by the Tukey-Kramer honestly test. No letters are presented when no significant difference was obtained.

\begin{tabular}{|c|c|c|c|c|c|c|c|c|c|c|c|c|c|c|}
\hline \multicolumn{5}{|c|}{2016} & \multicolumn{5}{|c|}{2017} & \multicolumn{5}{|c|}{2018} \\
\hline \multirow[t]{3}{*}{ Variable } & & Shoot & \multicolumn{2}{|c|}{ Tubers Weight } & \multirow[t]{2}{*}{ Variable } & & \multirow{2}{*}{$\begin{array}{c}\text { Shoot } \\
d w t\end{array}$} & \multicolumn{2}{|c|}{ Tubers Weight } & \multirow[t]{2}{*}{ Variable } & & \multirow{2}{*}{\begin{tabular}{|c|} 
Shoot \\
$d w t$
\end{tabular}} & \multicolumn{2}{|c|}{ Tubers Weight } \\
\hline & & dwt & fwt & dwt & & & & fwt & dwt & & & & fwt & $\mathrm{dwt}$ \\
\hline & & g plant $^{-1}$ & \multicolumn{2}{|c|}{$\mathrm{kg}_{\text {plant }}{ }^{-1}$} & & & $\underset{\text { plant }^{-1}}{\mathrm{~g}}$ & \multicolumn{2}{|c|}{$\mathrm{kg}_{\text {plant }}{ }^{-1}$} & & & $\underset{\text { plant }^{-1}}{\mathrm{~g}}$ & \multicolumn{2}{|c|}{$\mathrm{kg}_{\text {plant }}{ }^{-1}$} \\
\hline$C_{N}$ & & & & $\mathrm{C}_{\mathrm{N}}$ & $C_{N}$ & & & & & $C_{N}$ & & & & \\
\hline $\mathrm{mg} \mathrm{L}^{-1}$ & & & & $\mathrm{mg} \mathrm{L}^{-1}$ & $\mathrm{mg} \mathrm{L}^{-1}$ & & & & & $\mathrm{mg} \mathrm{L}^{-1}$ & & & & \\
\hline 10 & & $9.3 \mathrm{f}$ & $0.777 \mathrm{f}$ & $0.092 \mathrm{f}$ & 10 & & $34.1 \mathrm{~b}$ & $0.54 \mathrm{c}$ & $0.150 \mathrm{c}$ & 10 & & $6.3 \mathrm{c}$ & $0.229 \mathrm{c}$ & $0.029 \mathrm{c}$ \\
\hline 20 & & $16.5 \mathrm{e}$ & $1.132 \mathrm{e}$ & $0.133 \mathrm{e}$ & 50 & & $47.4 \mathrm{a}$ & $1.19 \mathrm{~b}$ & $0.351 \mathrm{~b}$ & 50 & & $32.2 \mathrm{~b}$ & $0.610 \mathrm{~b}$ & $0.077 \mathrm{~b}$ \\
\hline 30 & & $25.3 \mathrm{~d}$ & $1.540 \mathrm{~d}$ & $0.191 \mathrm{~d}$ & 100 & & $55.4 \mathrm{a}$ & $1.63 \mathrm{a}$ & $0.498 \mathrm{a}$ & 100 & & $49.0 \mathrm{a}$ & $0.693 \mathrm{ab}$ & $0.088 \mathrm{ab}$ \\
\hline 40 & & $33.0 \mathrm{c}$ & $1.916 \mathrm{c}$ & $0.229 \mathrm{c}$ & 150 & & $48.6 \mathrm{a}$ & $1.36 \mathrm{~b}$ & $0.418 \mathrm{ab}$ & 150 & & $57.4 \mathrm{a}$ & $0.811 \mathrm{a}$ & $0.109 a$ \\
\hline 60 & & $43.6 \mathrm{~b}$ & $2.397 \mathrm{~b}$ & $0.299 \mathrm{~b}$ & & & & & & & & & & \\
\hline 80 & & $53.6 \mathrm{a}$ & $2.640 \mathrm{a}$ & $0.354 \mathrm{a}$ & & & & & & & & & & \\
\hline $\mathrm{C}_{\mathrm{CL}}$ & & & & & $\mathrm{C}_{\mathrm{CL}}$ & & & & & $\mathrm{C}_{\mathrm{CL}}$ & & & & \\
\hline $\mathrm{mg} \mathrm{L}^{-1}$ & & & & & $\mathrm{mg} \mathrm{L}^{-1}$ & & & & & $\mathrm{mg} \mathrm{L}^{-1}$ & & & & \\
\hline 15 & & $20.8 \mathrm{c}$ & $1.686 \mathrm{ab}$ & $0.220 \mathrm{ab}$ & 15 & & 46.4 & 1.27 & 0.382 & 15 & & $49.6 \mathrm{a}$ & $0.753 \mathrm{ba}$ & $0.105 \mathrm{a}$ \\
\hline 150 & & $30.9 \mathrm{~b}$ & $1.843 \mathrm{a}$ & $0.234 \mathrm{a}$ & 150 & & 49.8 & 1.24 & 0.374 & 200 & & $49.6 \mathrm{a}$ & $0.771 \mathrm{a}$ & $0.103 \mathrm{ab}$ \\
\hline 350 & & $35.4 \mathrm{a}$ & $1.737 \mathrm{ab}$ & $0.209 \mathrm{~b}$ & 350 & & 43.8 & 1.1 & 0.331 & 600 & & $33.5 \mathrm{~b}$ & $0.582 \mathrm{bc}$ & $0.072 \mathrm{bc}$ \\
\hline 700 & & $33.9 \mathrm{ab}$ & $1.667 \mathrm{~b}$ & $0.203 \mathrm{~b}$ & 700 & & 45.6 & 1.1 & 0.329 & 1100 & & $29.5 \mathrm{~b}$ & $0.472 \mathrm{~cd}$ & $0.054 \mathrm{c}$ \\
\hline & & & & & & & & & & 1500 & & $19.0 \mathrm{~b}$ & $0.350 \mathrm{~d}$ & $0.045 \mathrm{c}$ \\
\hline Factor & $\mathrm{df}$ & Probability of F & & & Factor & $\mathrm{df}$ & & & & Factor & $\mathrm{df}$ & & & \\
\hline $\mathrm{C}_{\mathrm{Cl}}$ & 3 & $<0.0001$ & 0.0426 & 0.0031 & $\mathrm{C}_{\mathrm{Cl}}$ & 3 & 0.4991 & 0.1914 & 0.1533 & $\mathrm{C}_{\mathrm{Cl}}$ & 3 & $<0.0001$ & $<0.0001$ & $<0.0001$ \\
\hline $\mathrm{C}_{\mathrm{N}}$ & 3 & $<0.0001$ & $<0.0001$ & $<0.0001$ & $\mathrm{C}_{\mathrm{N}}$ & 3 & 0.0001 & $<0.0001$ & $<0.0001$ & $\mathrm{C}_{\mathrm{N}}$ & 4 & $<0.0001$ & $<0.0001$ & $<0.0001$ \\
\hline Block & 3 & 0.1232 & 0.4346 & 0.289 & Block & 3 & 0.0007 & 0.4065 & 0.3209 & Block & 3 & 0.6334 & 0.0095 & 0.0200 \\
\hline $\mathrm{C}_{\mathrm{N}} \times \mathrm{C}_{\mathrm{Cl}}$ & 9 & 0.0351 & 0.4951 & 0.025 & $\mathrm{C}_{\mathrm{N}} \times \mathrm{C}_{\mathrm{Cl}}$ & 9 & 0.4483 & 0.1892 & 0.3250 & $\mathrm{C}_{\mathrm{N}} \mathrm{XC} \mathrm{C}_{\mathrm{Cl}}$ & 12 & 0.0008 & 0.0435 & 0.3120 \\
\hline
\end{tabular}


The response of the tubers fresh weight to $C_{N}$ at each level of the studied $C_{C l}$ value is presented in Figure 2. In the first experiment, the highest tuber yield at all $\mathrm{C}_{\mathrm{Cl}}$ values was observed at the highest $\mathrm{C}_{\mathrm{N}}$ treatment, $80 \mathrm{mg} \mathrm{L}^{-1}$. However, the increase in mass as $\mathrm{C}_{\mathrm{N}}$ was raised from 60 to $80 \mathrm{mg} \mathrm{L}^{-1}$ was bigger as $\mathrm{C}_{\mathrm{Cl}}$ was lower: $407,317,220$, and $20 \mathrm{~g} \mathrm{plant}^{-1}$ for $15,150,350$, and $700 \mathrm{mg} \mathrm{L}^{-1}$, respectively. In the second experiment the highest tuber yield at all $\mathrm{C}_{\mathrm{Cl}}$ values was observed at $100 \mathrm{mg} \mathrm{L}^{-1}$. However, the increase in mass as $\mathrm{C}_{\mathrm{N}}$ was increased from 50 to $100 \mathrm{mg} \mathrm{l}^{-1}$ was bigger as $\mathrm{C}_{\mathrm{Cl}}$ was lower: 663, 642, 340 and $119 \mathrm{~g} \mathrm{plant}^{-1}$ for 15,150, 350 and $700 \mathrm{mg} \mathrm{L}^{-1}$, respectively. In the third experiment, the main difference in the tubers yields at the highest $C_{N}\left(150 \mathrm{mg} \mathrm{L}^{-1}\right)$ between $\mathrm{C}_{\mathrm{Cl}}$ treatments stemmed from the difference in the increase in yield as the $C_{N}$ was raised from 50 to 150 from $\mathrm{mg} \mathrm{L}^{-1}$.

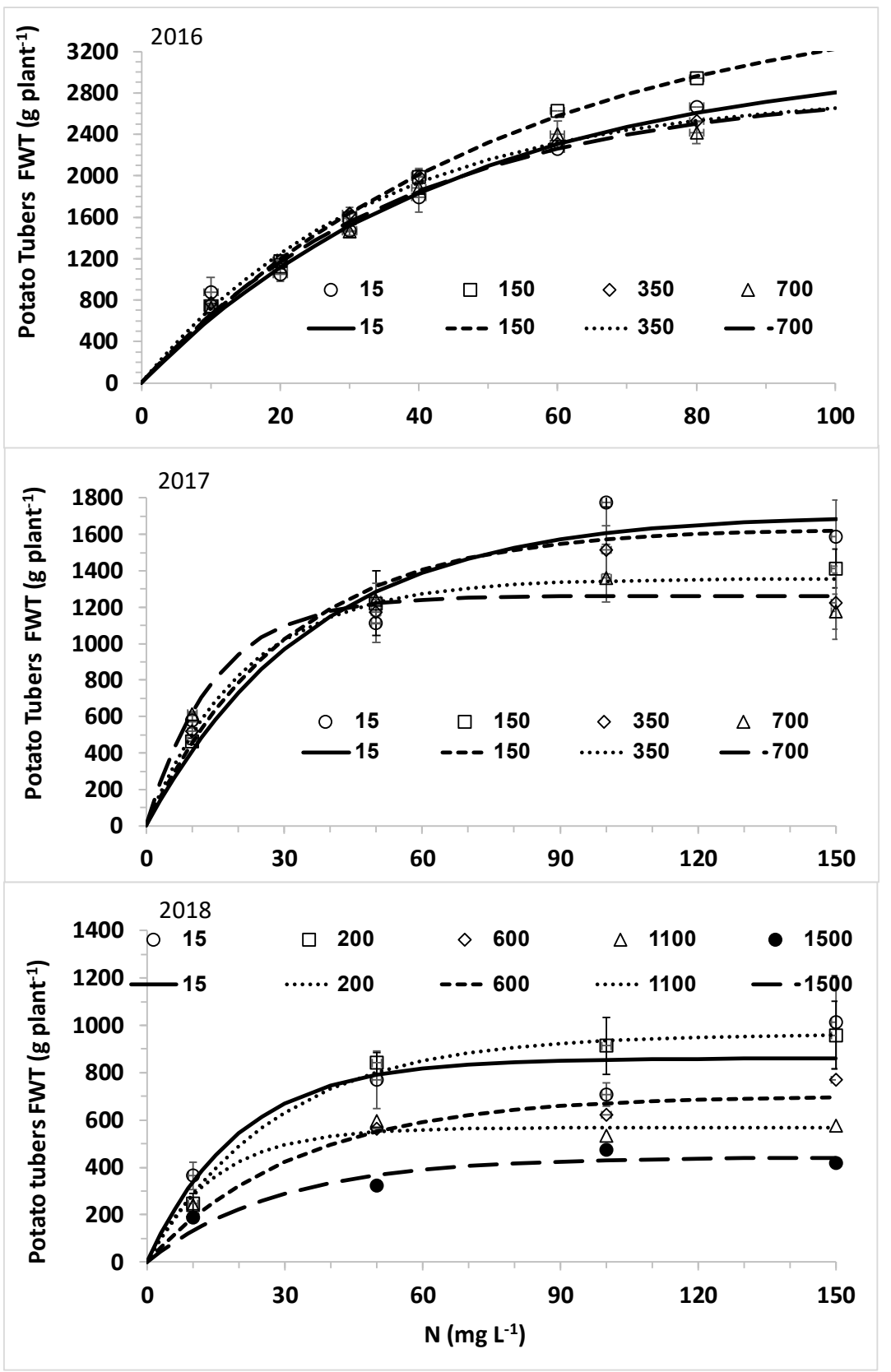

Figure 2. Potato tubers fresh weight (FWT) as a function of $\mathrm{N}$ concentration in the irrigating solution at different $\mathrm{Cl}$ concentrations in the irrigating solution, (bottom) 26 May 2016, (middle) May 2017, and (top) May 2018. 
All the curves in the second and third experiments show steep slope as $C_{N}$ increased from 0 to 20-30 $\mathrm{mg} \mathrm{L}^{-1}$ followed by moderate slope, and above $80-120 \mathrm{mg} \mathrm{L}^{-1}$ the curves approach maximal values according to the Mitcherlich equation with lower values for the high $\mathrm{C}_{\mathrm{Cl}}$ Equation (2). The visual fitness of the curves to the observed values for each $\mathrm{C}_{\mathrm{Cl}}$ value in the second and third years is satisfactory. In the first year only the first two stages of the curves (steep and moderate slope) appear as a result of the narrow $C_{N}$ range, $10-80 \mathrm{mg} \mathrm{L}^{-1}$, in comparison to $10-150 \mathrm{mg} \mathrm{L}^{-1}$ in the second and third experiments. In the first year, the effect of $\mathrm{C}_{\mathrm{Cl}}$ treatments was small and the interaction was insignificant, therefore only the curve at $150 \mathrm{mg} \mathrm{Cl} \mathrm{L}^{-1}$ is clearly separated from the other curves. The best fit values of the coefficients $A$ and $C$ at each $C_{C l}$ Equation (2) in the three potato experiments are presented in Table 5. In the three experiments the A values that are defined in the Mitcherlich equation as the maximal value for each $C_{C l}$ decrease as $C_{C l}$ increase above $150 \mathrm{mg} \mathrm{L}^{-1}$. In the first and third years, the A value of the desalinated water $\left(15 \mathrm{mg} \mathrm{L}^{-1}\right)$ was lower than that of 150 and $200 \mathrm{mg}$ $\mathrm{L}^{-1}$; these values are in the range of concentrations of natural water sources used for irrigation in Israel and other semiarid and arid regions. In the third experiment, in which the range of $\mathrm{C}_{\mathrm{Cl}}$ was extended from 700 to $1500 \mathrm{mg} \mathrm{L}^{-1}$, the strongest impact on A was obtained. The $C$ coefficient can be used to calculate the $C_{N}$ value to obtain any percentage of the maximal yield at each $C_{C l}$. Thus, the $C_{N}$ value for achieving $95 \%$ of the maximal yield $\left(\mathrm{C}_{\mathrm{N} 95}\right)$ at each $\mathrm{C}_{\mathrm{Cl}}$ was calculated and presented in Table 5 . In the first and second experiments, the general trend is reduction in $\mathrm{C}_{\mathrm{N} 95}$ as $\mathrm{C}_{\mathrm{Cl}}$ increased above 150 and $15 \mathrm{mg} \mathrm{L}^{-1}$, respectively. In both years the calculated $\mathrm{C}_{\mathrm{N} 95}$ for desalinated water is higher than that for the two highest salinities, 350 and $700 \mathrm{mg} \mathrm{L}^{-1}$, in contrast to the assumption that the required $\mathrm{C}_{\mathrm{N}}$ for optimal yield will be lower for desalinated water. In the third year, no clear trend in the effect of $\mathrm{C}_{\mathrm{Cl}}$ on the calculated $\mathrm{C}_{\mathrm{N} 95}$ was obtained, probably because of the big effect of $\mathrm{C}_{\mathrm{Cl}}$ on the $\mathrm{A}$ value, which is highly correlated with $C$.

Table 5. Best fit parameters of the Mitcherlich equation for best fit curves of Potato tubers fresh weight as a function of $\mathrm{N}$ concentration in the irrigating solution at different $\mathrm{Cl}$ concentrations in the irrigating solutions (Figure 2). Numbers in brackets are the standard errors of the estimated parameters. The values of the parameters and their standard errors were determined using the Nlin procedure of JMP 14.

\begin{tabular}{cccc}
\hline $\mathbf{C l}$ & $\mathbf{A}$ & $\mathbf{C}$ & $\mathbf{N}(\mathbf{Y}=\mathbf{9 5} \%)$ Optimum \\
\hline $\mathrm{mg} \mathrm{L}^{-1}$ & & 2016 & \\
\hline 15 & $3163(471)$ & $0.022(0.006)$ & 137.9 \\
\hline 150 & $3810(272)$ & $0.019(0.002)$ & 159.8 \\
\hline 350 & $2794(111)$ & $0.030(0.002)$ & 101.0 \\
\hline 700 & $2849(160)$ & $0.026(0.003)$ & 113.9 \\
\hline 15 & & 2017 & 107.7 \\
\hline 150 & $1712(178)$ & $0.028(0.010)$ & 91.0 \\
\hline 350 & $1632(128)$ & $0.033(0.010)$ & 64.1 \\
\hline 700 & $1356(91)$ & $0.047(0.013)$ & 43.8 \\
\hline & $1262(57)$ & $0.068(0.015)$ & 59.9 \\
\hline 15 & & 2018 & 84.3 \\
\hline 200 & $860(87)$ & $0.050(0.024)$ & 110.9 \\
\hline 600 & $963(76)$ & $0.0355(0.011)$ & 43.8 \\
\hline 1100 & $737(92)$ & $0.027(0.012)$ & 84.8 \\
\hline 1500 & $568(53)$ & $0.068(0.051)$ & \\
\hline & $443(63)$ & $0.0353(0.021)$ & \\
\hline
\end{tabular}

\section{2. $\mathrm{N}$ and $\mathrm{Cl}$ Concentrations in Plants Leaves}

For achieving the second objective, we determined the concentrations of $\mathrm{N}$ and $\mathrm{Cl}$ in organs of lettuce and potato grown at different combinations of $\mathrm{C}_{\mathrm{N}}$ and $\mathrm{C}_{\mathrm{Cl}}$ in the experiments described in the previous section. 


\subsection{1. $\mathrm{N}$ and $\mathrm{Cl}$ Concentrations in Lettuce Heads and Roots}

In the first and second lettuce experiments, $\mathrm{N}$ concentration in lettuce head was significantly affected by $\mathrm{C}_{\mathrm{N}}$, but was not affected by $\mathrm{C}_{\mathrm{CL}}$, and no significant interaction between these factors was obtained (Table 6). In both experiments $\mathrm{N}$ concentration in lettuce roots was significantly affected by $\mathrm{C}_{\mathrm{N}}$ and it was significantly affected by $\mathrm{C}_{\mathrm{CL}}$ in the first experiment, while no significant effect was obtained in the second experiment. In both experiments, no significant interaction between these factors on $\mathrm{N}$ concentration in the roots was obtained. In both experiments, $\mathrm{N}$ concentrations in lettuce head and roots increased significantly with raising $C_{N}$ from the lowest value of 25 up to $75 \mathrm{mg} \mathrm{L}^{-1}$ in the first experiment and $140 \mathrm{mg} \mathrm{L}^{-1}$ in the second experiment. In the first experiment $\mathrm{N}$ concentration in the roots decreased significantly as $\mathrm{C}_{\mathrm{Cl}}$ was raised from 15 to $700 \mathrm{mg} \mathrm{L}^{-1}$, however the effect was relatively small, just an $11 \%$ difference. As expected nitrate concentration in lettuce head increased significantly as $\mathrm{C}_{\mathrm{N}}$ increased. $\mathrm{C}_{\mathrm{Cl}}$ had also significant effect on nitrate concentration in lettuce head, but no significant interaction between these factors was obtained. $\mathrm{N}$ concentration in the roots increased from 0.62 to $3.51 \mathrm{mg} \mathrm{N} \mathrm{g}^{-1}$ with increasing $\mathrm{C}_{\mathrm{N}}$ from the lowest to the highest value, 25 and $140 \mathrm{mg} \mathrm{L}^{-1}$, respectively. Although the effect of $\mathrm{C}_{\mathrm{Cl}}$ on nitrate concentration was significant it was inconsistent and the differences between treatments were relatively small. The highest and the lowest values were obtained with 15 and $150 \mathrm{mg} \mathrm{Cl} \mathrm{L}^{-1}$, whereas no significant differences were obtained between these treatments and the two other treatments (350 and $700 \mathrm{mg} \mathrm{Cl} \mathrm{L}^{-1}$ ).

Table 6. The effect of $\mathrm{C}_{\mathrm{N}}$ and $\mathrm{C}_{\mathrm{CL}}$ on $\mathrm{N}, \mathrm{Cl}$, and nitrate- $\mathrm{N}$ concentrations in lettuce head and roots. The probability of $F$ values for $C_{N}, C_{C l}$, Block factors, and the interaction of $C_{N}$ and $C_{C l}$ was determined using the two-way ANOVA procedure of JMP 14. Different letters on the right side of values indicate significant difference between treatments (HSD) at $p<0.05$ by the Tukey-Kramer honestly test. No letters are presented when no significant difference was obtained.

\begin{tabular}{|c|c|c|c|c|c|c|c|c|c|}
\hline \multicolumn{7}{|c|}{2016} & \multicolumn{3}{|c|}{2017} \\
\hline & & & Head & & Roots & & & Head & Roots \\
\hline \multicolumn{2}{|l|}{ Variable } & $\mathbf{N}$ & $\mathrm{Cl}$ & Nitrate-N & $\mathbf{N}$ & $\mathrm{Cl}$ & Variable & $\mathbf{N}$ & $\mathbf{N}$ \\
\hline \multicolumn{2}{|l|}{$C_{N}$} & & & & \multicolumn{5}{|c|}{$\mathrm{C}_{\mathrm{N}}$} \\
\hline \multicolumn{2}{|l|}{$\mathrm{mg} \mathrm{L}^{-1}$} & \multicolumn{4}{|c|}{$\mathrm{mg} \mathrm{g}^{-1}$} & & $\mathrm{mg} \mathrm{L}^{-1}$ & \multicolumn{2}{|c|}{$\mathrm{mg} \mathrm{g}^{-1}$} \\
\hline \multicolumn{2}{|l|}{25} & $28.4 \mathrm{c}$ & $30.8 \mathrm{a}$ & $0.62 \mathrm{~d}$ & $15.3 \mathrm{~d}$ & $30.3 \mathrm{ab}$ & 25 & $24.9 \mathrm{e}$ & $10.8 \mathrm{~d}$ \\
\hline \multicolumn{2}{|l|}{50} & $34.4 \mathrm{~b}$ & $28.0 \mathrm{ab}$ & $1.26 \mathrm{c}$ & $21.9 \mathrm{c}$ & $32.4 \mathrm{a}$ & 45 & $32.8 \mathrm{~d}$ & $13.0 \mathrm{~cd}$ \\
\hline \multicolumn{2}{|l|}{75} & $40.1 \mathrm{a}$ & $25.1 \mathrm{bc}$ & $1.86 \mathrm{~b}$ & $22.4 \mathrm{c}$ & $24.9 \mathrm{bc}$ & 65 & $36.7 \mathrm{c}$ & $15.6 \mathrm{bc}$ \\
\hline \multicolumn{2}{|l|}{100} & $40.8 \mathrm{a}$ & $23.1 \mathrm{c}$ & $2.27 \mathrm{~b}$ & $27.9 \mathrm{~b}$ & $29.0 a b c$ & 85 & $42.4 \mathrm{~b}$ & $16.3 \mathrm{bc}$ \\
\hline \multicolumn{2}{|l|}{125} & $43.1 \mathrm{a}$ & $21.1 \mathrm{c}$ & $3.14 \mathrm{a}$ & $29.5 \mathrm{ab}$ & $25.7 a b c$ & 100 & $44.5 \mathrm{~b}$ & $19.0 \mathrm{ab}$ \\
\hline \multicolumn{2}{|l|}{140} & $43.0 \mathrm{a}$ & $20.9 c$ & $3.51 \mathrm{a}$ & $32.0 \mathrm{a}$ & $23.2 \mathrm{c}$ & 125 & $48.2 \mathrm{a}$ & $20.7 \mathrm{a}$ \\
\hline \multicolumn{2}{|l|}{$\mathrm{C}_{\mathrm{CL}}{ }^{1}$} & & & & & & $\mathrm{C}_{\mathrm{CL}}$ & & \\
\hline \multicolumn{2}{|l|}{$\mathrm{mg} \mathrm{L}^{-1}$} & & & & & & $\mathrm{mg} \mathrm{L}^{-1}$ & & \\
\hline \multicolumn{2}{|l|}{15} & 38 & $10.5 c$ & $2.36 \mathrm{a}$ & $26.9 \mathrm{a}$ & $4.6 \mathrm{c}$ & 15 & 38.9 & 16.8 \\
\hline \multicolumn{2}{|l|}{150} & 38 & $26.2 \mathrm{~b}$ & $1.92 \mathrm{~b}$ & $25.1 \mathrm{ab}$ & $26.5 \mathrm{~b}$ & 150 & 37.3 & 16.3 \\
\hline \multicolumn{2}{|l|}{350} & 39.2 & $29.5 b$ & $2.05 \mathrm{ab}$ & $24.5 \mathrm{ab}$ & $37.3 \mathrm{a}$ & 350 & 38.2 & 14.7 \\
\hline \multicolumn{2}{|l|}{700} & 37.9 & $33.2 \mathrm{a}$ & $2.09 \mathrm{ab}$ & $22.9 \mathrm{~b}$ & $42.0 \mathrm{a}$ & 700 & 38.6 & 15.8 \\
\hline Factor & $\mathrm{df}$ & \multicolumn{5}{|c|}{ Probability of $F$} & Factor & \multicolumn{2}{|c|}{ Probability of $F$} \\
\hline $\mathrm{C}_{\mathrm{N}}$ & 5 & $<0.0001$ & $<0.0001$ & $<0.0001$ & $<0.0001$ & 0.0011 & $\mathrm{C}_{\mathrm{N}}$ & $<0.0001$ & $<0.0001$ \\
\hline $\mathrm{C}_{\mathrm{CL}}$ & 3 & 0.775 & $<0.0001$ & 0.0241 & 0.0064 & $<0.0001$ & $\mathrm{C}_{\mathrm{CL}}$ & 0.2601 & 0.1658 \\
\hline Block & 3 & 0.0457 & 0.3559 & 0.8499 & 0.7811 & 0.9054 & Block & 0.3707 & 0.5010 \\
\hline $\mathrm{C}_{\mathrm{N}} \mathrm{XC}_{\mathrm{Cl}}$ & 15 & 0.9030 & 0.5901 & 0.2804 & 0.8282 & 0.2963 & $\mathrm{C}_{\mathrm{N}} \mathrm{XC}_{\mathrm{Cl}}$ & 0.5748 & 0.2453 \\
\hline
\end{tabular}

$\mathrm{Cl}$ concentration in lettuce head and roots were significantly affected by $\mathrm{C}_{\mathrm{N}}$ and by $\mathrm{C}_{\mathrm{CL}}$ and no significant interaction between these factors was obtained (Table 6). As expected, $\mathrm{Cl}$ concentration in lettuce head and roots increased significantly from 10.8 to $33.2 \mathrm{mg} \mathrm{g}^{-1}$ and from 5.1 to $42.0 \mathrm{mg} \mathrm{g}^{-1}$ with 
increasing $\mathrm{C}_{\mathrm{Cl}}$ from the lowest to the highest value, 15 and $700 \mathrm{mg} \mathrm{L}^{-1}$, respectively. In agreement with the hypothesis, $\mathrm{Cl}$ concentration in lettuce head and roots decreased significantly from 30.8 to $20.9 \mathrm{mg} \mathrm{g}^{-1}$ and from 30.3 to $23.2 \mathrm{mg} \mathrm{g}^{-1}$, respectively, with increasing $\mathrm{C}_{\mathrm{N}}$ from the lowest to the highest value, 25 and $140 \mathrm{mg} \mathrm{L}^{-1}$.

The correlation of the mean $\mathrm{Cl}$ concentrations for all $\mathrm{C}_{\mathrm{Cl}}$ levels in lettuce heads and roots with the respective $\mathrm{N}$ concentrations in these organs in 2016 was examined. High correlation $\left(\mathrm{r}^{2}=0.95\right)$ was obtained for $\mathrm{Cl}$ vs. $\mathrm{N}$ in lettuce head with significant slope $(p=0.0008)$. In the root the correlation was low, $\mathrm{r}^{2}=0.47$, and the slope was insignificant.

\subsection{2. $\mathrm{N}$ and $\mathrm{Cl}$ Concentrations in Potato Leaves and Tubers}

In the three potato experiments, $\mathrm{N}$ concentrations in the leaves and tubers were significantly affected by $\mathrm{C}_{\mathrm{N}}$, but were not affected by $\mathrm{C}_{\mathrm{CL}}$ and no significant interaction between these factors was obtained (Table $7 \mathrm{a}, \mathrm{b})$. In the three potato experiments, $\mathrm{N}$ concentrations in the leaves and tubers increased significantly with raising $\mathrm{C}_{\mathrm{N}}$ from 10 to $80 \mathrm{mg} \mathrm{L}^{-1}$ in the first experiment, from 10 to $150 \mathrm{mg} \mathrm{L}^{-1}$ in the second and third experiments, independently of the $\mathrm{C}_{\mathrm{Cl}}$ level (Table $\left.7 \mathrm{a}, \mathrm{b}\right)$. In the second and third experiments there was gradual decrease in the effect of $\mathrm{C}_{\mathrm{N}}$ on $\mathrm{N}$ concentrations in the leaves and tubers as $\mathrm{C}_{\mathrm{N}}$ became higher. Nitrate concentration in potato leaves was determined just in the first potato experiment and like the reduced $\mathrm{N}$ it was significantly affected by $\mathrm{C}_{\mathrm{N}}$. In contrast to the reduced $\mathrm{N}$ nitrate concentration in potato leaves was also significantly affected by $\mathrm{C}_{\mathrm{Cl}}$ and a significant interaction between these factors was also obtained. Despite this significant interaction effect the major effect of each factor $\left(\mathrm{C}_{\mathrm{N}}\right.$ and $\left.\mathrm{C}_{\mathrm{Cl}}\right)$ is presented and discussed, because the interaction effect is due to differences in the magnitude of the $\mathrm{C}_{\mathrm{Cl}}$ effect with each $\mathrm{C}_{\mathrm{N}}$ level, rather than the direction of the effect. The nitrate concentration in the leaves increased gradually from 0.41 to $1.53 \mathrm{mg} \mathrm{g}^{-1}$ with the incremental raise of $\mathrm{C}_{\mathrm{N}}$ from 10 to $80 \mathrm{mg} \mathrm{L}^{-1}$. Note that the concentration of the reduced $\mathrm{N}$ was 20 to 56 times that of nitrate- $\mathrm{N}$.

$\mathrm{Cl}$ concentrations in the shoot were significantly affected by both $\mathrm{C}_{\mathrm{Cl}}$ and $\mathrm{C}_{\mathrm{N}}$ with significant interaction between these factors in all three experiments (Table $7 a, b)$. In the first and second experiments, $\mathrm{Cl}$ concentrations in the tubers were also significantly affected by both $\mathrm{C}_{\mathrm{Cl}}$ and $\mathrm{C}_{\mathrm{N}}$ with significant interaction between these factors, whereas in the third experiment it was affected significantly just by $C_{C l}$. The interaction effect of $C_{N}$ and $C_{C l}$ in all cases is due to differences in the magnitude of the $C_{C l}$ effect with each $C_{N}$ level, rather than the direction of the effect. Therefore, we present the major effects of $\mathrm{C}_{\mathrm{N}}$ and $\mathrm{C}_{\mathrm{Cl}}$. Overall, $\mathrm{Cl}$ concentrations in the shoot and tubers increased with increasing $\mathrm{C}_{\mathrm{Cl}}$, with reduction in the relative effect as the $\mathrm{C}_{\mathrm{Cl}}$ became higher. In the majority of cases, $\mathrm{Cl}$ concentrations in shoot and tubers decreased with raising the $\mathrm{C}_{\mathrm{N}}$, except non-consistent effect of $\mathrm{C}_{\mathrm{N}}$ on $\mathrm{Cl}$ concentration in the shoot in the first potato experiment and nonsignificant effect on $\mathrm{Cl}$ concentration in the tuber in the third potato experiment.

The correlation of the mean $\mathrm{Cl}$ concentrations for all $\mathrm{C}_{\mathrm{Cl}}$ levels in leaves and tubers with the respective $\mathrm{N}$ concentrations in these organs was examined. In the first experiment, high correlation $\left(\mathrm{r}^{2}=0.87\right)$ was obtained for $\mathrm{Cl}$ vs. $\mathrm{N}$ in the potato leaves with significant slope $(p=0.0216)$ for all $\mathrm{C}_{\mathrm{N}}$ treatments, excluding the lowest $\mathrm{C}_{\mathrm{N}}$ level in which low $\mathrm{Cl}$ leaf concentration was obtained. High correlation $\left(r^{2}=0.76\right)$ was also obtained in the tubers and the slope was also significant $(p=0.0238)$. In the second experiment, high correlation $\left(\mathrm{r}^{2}=0.85\right)$ was obtained for $\mathrm{Cl}$ vs. $\mathrm{N}$ in the potato leaves, but the slope was insignificant $(p=0.0762)$. High correlation $\left(\mathrm{r}^{2}=0.88\right)$ was also obtained in the tubers, and, although the slope was not significant, it indicates tendency $(p=0.06)$. In the third experiment, high correlation $\left(\mathrm{r}^{2}=0.89\right)$ was obtained for $\mathrm{Cl}$ vs. $\mathrm{N}$ in the potato leaves, with $p$-value of the slope very close to significant value $(p=0.052)$. High correlation $\left(\mathrm{r}^{2}=0.94\right)$ was also obtained in the tubers with significant value $(p=0.0322)$. Lower correlation $\left(\mathrm{r}^{2}=0.42\right)$ for $\mathrm{Cl}$ leaf with $\mathrm{N}$ leaf over all the experiments together was obtained but the slope was highly significant $(p=0.0169)$. High correlation $\left(\mathrm{r}^{2}=0.92\right)$ for $\mathrm{Cl}$ leaf with $\mathrm{N}$ leaf over all the experiments together was obtained and the slope was also highly significant $(p \leq 0.0001)$. 
Table 7. The effect of $\mathrm{C}_{\mathrm{N}}$ and $\mathrm{C}_{\mathrm{CL}}$ on the concentrations of (a) $\mathrm{N}$ and nitrate-N, and (b) $\mathrm{Cl}$ in Potato leaves and tubers. Probability of $F$ values for $\mathrm{C}_{\mathrm{N}}, \mathrm{C}_{\mathrm{Cl}}$, Block factors, and the interaction of $\mathrm{C}_{\mathrm{N}}$ and $\mathrm{C}_{\mathrm{Cl}}$ were determined using the two-way ANOVA procedure of JMP 14. Different letters on the right side of values indicate significant difference between treatments (HSD) at $p<0.05$ by the Tukey-Kramer honestly test. No letters are presented when no significant difference was obtained.

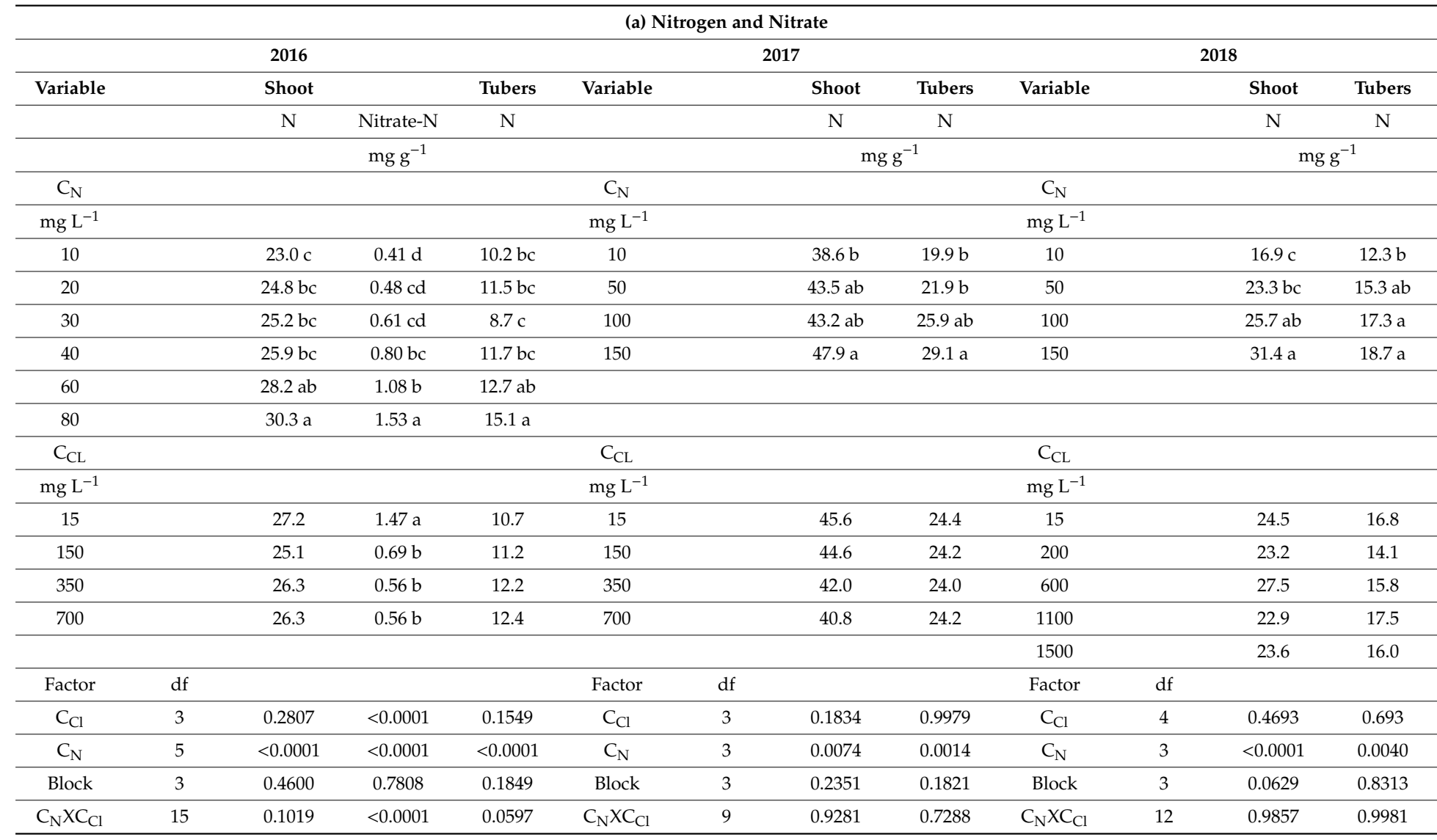


Table 7. Cont

\begin{tabular}{|c|c|c|c|c|c|c|c|c|c|c|c|}
\hline \multicolumn{12}{|c|}{ (b) Chloride } \\
\hline & & & & 2017 & & & & 2018 & & & \\
\hline \multirow[t]{3}{*}{ Variable } & & Shoot & Tubers & Variable & & & Shoot & Tubers & Variable & Shoot & Tubers \\
\hline & & $\mathrm{Cl}$ & & & & $\mathrm{Cl}$ & & & & $\mathrm{Cl}$ & \\
\hline & & $\mathrm{mg} \mathrm{g}^{-1}$ & & & & \multicolumn{4}{|c|}{$\mathrm{mg} \mathrm{g}^{-1}$} & \multicolumn{2}{|c|}{$\mathrm{mg} \mathrm{g}^{-1}$} \\
\hline$C_{N}$ & & & & $C_{N}$ & \multicolumn{7}{|c|}{$C_{N}$} \\
\hline $\mathrm{mg} \mathrm{l}^{-1}$ & & & & $\mathrm{mg} \mathrm{L}^{-1}$ & \multicolumn{7}{|c|}{$\mathrm{mg} \mathrm{L}^{-1}$} \\
\hline 10 & & $71.0 \mathrm{~d}$ & $18.4 \mathrm{a}$ & 10 & & $70.7 \mathrm{a}$ & $14.8 \mathrm{a}$ & 10 & & $68.7 \mathrm{a}$ & 16.0 \\
\hline 20 & & $92.0 \mathrm{a}$ & $19.2 \mathrm{a}$ & 50 & & $52.4 \mathrm{~b}$ & $10.0 \mathrm{~b}$ & 50 & & $60.2 \mathrm{a}$ & 14.5 \\
\hline 30 & & $86.1 \mathrm{ab}$ & $18.9 \mathrm{a}$ & 100 & & $39.3 \mathrm{c}$ & $7.3 \mathrm{c}$ & 100 & & $49.5 \mathrm{~b}$ & 13.8 \\
\hline 40 & & $79.4 \mathrm{bc}$ & $17.2 \mathrm{ab}$ & 150 & & $31.8 \mathrm{~d}$ & $5.8 \mathrm{~d}$ & 150 & & $47.0 \mathrm{~b}$ & 12.0 \\
\hline 60 & & $72.2 \mathrm{~cd}$ & $15.3 \mathrm{bc}$ & & & & & & & & \\
\hline 80 & & $69.2 \mathrm{~d}$ & $14.1 \mathrm{c}$ & & & & & & & & \\
\hline $\mathrm{C}_{\mathrm{CL}}$ & & & & $\mathrm{C}_{\mathrm{CL}}$ & & & & $\mathrm{C}_{\mathrm{CL}}$ & & & \\
\hline $\mathrm{mg} \mathrm{l}^{-1}$ & & & & $\mathrm{mg} \mathrm{l}^{-1}$ & & & & $\mathrm{mg} \mathrm{l}^{-1}$ & & & \\
\hline 15 & & $27.1 \mathrm{c}$ & $9.0 \mathrm{~d}$ & 15 & & $18.5 \mathrm{c}$ & $4.5 \mathrm{~d}$ & 15 & & $33.7 \mathrm{~b}$ & $8.8 \mathrm{~b}$ \\
\hline 150 & & $73.9 \mathrm{~b}$ & $16.0 \mathrm{c}$ & 150 & & $46.8 \mathrm{~b}$ & $9.3 \mathrm{c}$ & 200 & & & \\
\hline 350 & & $103.9 \mathrm{a}$ & $20.6 \mathrm{~b}$ & 350 & & $62.5 \mathrm{a}$ & $11.0 \mathrm{~b}$ & 600 & & $64.8 \mathrm{a}$ & $15.4 \mathrm{a}$ \\
\hline \multirow[t]{2}{*}{700} & & $108.6 \mathrm{a}$ & $23.2 \mathrm{a}$ & 700 & & $66.5 \mathrm{a}$ & $13.1 \mathrm{a}$ & 1100 & & & \\
\hline & & & & & & & & 1500 & & $70.5 \mathrm{a}$ & $18.0 \mathrm{a}$ \\
\hline Factor & $\mathrm{df}$ & & & Factor & $\mathrm{df}$ & & & Factor & $\mathrm{df}$ & & \\
\hline $\mathrm{C}_{\mathrm{Cl}}$ & 3 & $<0.0001$ & $<0.0001$ & $\mathrm{C}_{\mathrm{Cl}}$ & 3 & $<0.0001$ & $<0.0001$ & $\mathrm{C}_{\mathrm{Cl}}$ & 2 & $<0.0001$ & $<0.0001$ \\
\hline $\mathrm{C}_{\mathrm{N}}$ & 5 & $<0.0001$ & $<0.0001$ & $\mathrm{C}_{\mathrm{N}}$ & 3 & $<0.0001$ & $<0.0001$ & $\mathrm{C}_{\mathrm{N}}$ & 3 & $<0.0001$ & 0.1082 \\
\hline Block & 3 & 0.1575 & 0.8786 & Block & 3 & 0.9066 & 0.0870 & Block & 3 & 0.2781 & 0.2980 \\
\hline $\mathrm{C}_{\mathrm{N}} \mathrm{XC}_{\mathrm{Cl}}$ & 15 & $<0.0001$ & 0.0502 & $\mathrm{C}_{\mathrm{N}} \times \mathrm{C}_{\mathrm{Cl}}$ & 9 & 0.0005 & $<0.0001$ & $\mathrm{C}_{\mathrm{N}} \mathrm{X} \mathrm{C}_{\mathrm{Cl}}$ & 6 & 0.0005 & 0.7343 \\
\hline
\end{tabular}




\subsection{Leaching Fraction and Leachate Composition}

For achieving the third objective, we determined the volume of the drainage and the concentrations of $\mathrm{N}$ and $\mathrm{Cl}$ in the leachate as affected by the $\mathrm{C}_{\mathrm{N}}$ and $\mathrm{C}_{\mathrm{Cl}}$ in the described experiments in the previous sections.

\subsubsection{Leaching Fraction and Leachate Composition in the Lettuce Experiments}

The leachate fractions (LF) in the lettuce experiments were high, above 0.5 , due to the excess irrigation used in order to obtain drainage for estimating the water composition in the growth medium. High dose and frequent irrigation were also required in the coarse sand to maintain available water for plants. In the first lettuce experiment, the LF was very high above 0.7 in all treatments (Table 8), due to high dose and frequent irrigations after transplanting. This irrigation management was practiced for preventing water shortage and drying in the high potential evaporation conditions in middle to the end of August (17 to 31 August 2016). During the two last weeks of the lettuce growth, a shading screen was set above the plants, reducing the direct irradiation, wind speed, and the potential transpiration, leading to lower LF values that ranged between 0.5 to 0.62 . In the second lettuce experiment, the LF was much lower, in the range of 0.3 to 0.5, as a result of transplanting in September and set up of the shading screen before transplanting. In the first experiment, LF increased slightly to a peak value as $C_{N}$ increased from 25 up to $75 \mathrm{mg} \mathrm{N} \mathrm{L}^{-1}$, but it decreased with further increasing of $\mathrm{C}_{\mathrm{N}}$. The LF was also affected significantly by $\mathrm{C}_{\mathrm{Cl}}$, and a significant interaction of $\mathrm{C}_{\mathrm{N}}$ with $\mathrm{C}_{\mathrm{Cl}}$ was obtained. This interaction is due to differences in the relative effect of $C_{N}$ at the different $C_{C l}$ levels, but no difference in the general trend. In the second lettuce experiment, both $\mathrm{C}_{\mathrm{N}}$ and $\mathrm{C}_{\mathrm{Cl}}$ had a significant effect on $\mathrm{LF}$, and also a significant interaction was obtained. The highest values of LF were obtained at $C_{N} 25$ and $125 \mathrm{mg} \mathrm{N}$ $\mathrm{L}^{-1}$ with significant lower values at the $\mathrm{C}_{\mathrm{N}}$ range of 45 to $100 \mathrm{mg} \mathrm{N} \mathrm{L}^{-1}$. The Lf increased significantly from $0.37-0.40$ to $0.44-0.45$ with increasing the $C_{\mathrm{Cl}}$ from $15-150$ to $350-700 \mathrm{mg} \mathrm{Cl} \mathrm{L}^{-1}$. The significant interaction of $C_{N}$ with $C_{C l}$ is due to differences in the relative effect of $C_{N}$ at the different $C_{C l}$ levels, but no difference in the general trend. The effects of $C_{N}$ and $C_{C l}$ on LF showed a general expected trend, as the biomass was higher the LF became lower.

The drainage $\mathrm{N}$ concentration $\left(\mathrm{C}_{\mathrm{NL}}\right)$ in both lettuce experiments increased with $\mathrm{C}_{\mathrm{N}}$ with significant differences between all $C_{N}$ levels (Table 8). The $C_{N L}$ in 2016 was lower than the corresponding $C_{N}$ values, whereas the opposite results were observed in 2017, probably due to the higher LF values in 2016 than 2017. In both years, $C_{N L}$ increased steeply as $C_{N}$ increased. $C_{C l}$ had no significant effect on $\mathrm{C}_{\mathrm{NL}}$ in the first lettuce experiments. In in the second experiment, significant higher values were obtained at $\mathrm{C}_{\mathrm{Cl}}=700 \mathrm{mg} \mathrm{L}^{-1}$ than all other $\mathrm{C}_{\mathrm{Cl}}$ treatments, but the relative effect of $\mathrm{C}_{\mathrm{Cl}}$ was much smaller than the effect of $C_{N}$. Although a significant interaction of $C_{N}$ with $C_{C l}$ was obtained in 2017, the general trend of $C_{N}$ effect on $C_{N L}$ was similar at all $C_{C l}$ concentrations with differences in the relative effect. The drainage $N$ mass $\left(M_{N L}\right)$ in both lettuce experiments increased with $C_{N}$ with significant differences between all $C_{N}$ levels, similar to the $C_{N L}$. While higher $C_{N L}$ values were obtained in 2017 than in 2016, the opposite effect on $\mathrm{M}_{\mathrm{NL}}$ was obtained, due to the much higher LF values in 2016. In the first experiment, the $\mathrm{M}_{\mathrm{NL}}$ increased linearly with $\mathrm{C}_{\mathrm{N}}$, while in the second experiment it increased exponentially, with steeper increase in $\mathrm{M}_{\mathrm{NL}}$ as $\mathrm{C}_{\mathrm{N}}$ increased above $85 \mathrm{mg} \mathrm{N} \mathrm{L}^{-1}$ (Figure 3). While $\mathrm{C}_{\mathrm{Cl}}$ had no effect on $\mathrm{M}_{\mathrm{Nl}}$ in the first experiment, it had a significant effect in the second experiment (Table 8 and Figure 3), in which the relative effect on $\mathrm{M}_{\mathrm{NL}}$ was much bigger than on $\mathrm{C}_{\mathrm{NL}}$., probably due to the effect of $\mathrm{C}_{\mathrm{Cl}}$ on LF. 
Table 8. Leaching fraction, the concentrations of $\mathrm{N}$ and $\mathrm{Cl}$ in the leachate $\left(\mathrm{C}_{\mathrm{NL}}\right.$ and $\left.\mathrm{C}_{\mathrm{ClL}}\right)$ and the mass of $\mathrm{N}$ and $\mathrm{Cl}$ in the leachate $\left(\mathrm{M}_{\mathrm{NL}}\right.$ and $\left.\mathrm{M}_{\mathrm{CIL}}\right)$ and the ratio of $\mathrm{M}_{\mathrm{NL}}$ of the applied $\mathrm{N}$ of the lettuce experiments. Probability of $F$ values for $\mathrm{C}_{\mathrm{N}}, \mathrm{C}_{\mathrm{Cl}}$, Block factors, and the interaction of $\mathrm{C}_{\mathrm{N}}$ and $\mathrm{C}_{\mathrm{Cl}}$ were determined using the two-way ANOVA procedure of JMP 14. Different letters on the right side of values indicate significant difference between treatments (HSD) at $p<0.05$ by the Tukey-Kramer honestly test. No letters are presented when no significant difference was obtained.

\begin{tabular}{|c|c|c|c|c|c|c|c|c|c|c|c|c|c|}
\hline \multirow{2}{*}{\multicolumn{2}{|c|}{ Variable }} & \multicolumn{5}{|c|}{2016} & \multicolumn{7}{|c|}{2017} \\
\hline & & LF & $\mathrm{C}_{\mathrm{NL}}$ & $\mathbf{M}_{\mathrm{NL}}$ & $\mathrm{C}_{\mathrm{CIL}}$ & $\mathbf{M}_{\mathrm{ClL}}$ & Variabl & & LF & $\mathrm{C}_{\mathrm{NL}}$ & $\mathbf{M}_{\mathrm{NL}}$ & $\mathrm{C}_{\mathrm{ClL}}$ & $\mathbf{M}_{\mathrm{ClL}}$ \\
\hline & & & $\mathrm{mg} \mathrm{L}^{-1}$ & $\mathrm{~g} \mathrm{pot}^{-1}$ & $\mathrm{mg} \mathrm{L}^{-1}$ & $\mathrm{~g} \mathrm{pot}^{-1}$ & & & & $\mathrm{mg} \mathrm{L}^{-1}$ & $\mathrm{~g} \mathrm{pot}^{-1}$ & $\mathrm{mg} \mathrm{L}^{-1}$ & $\mathrm{~g} \mathrm{pot}^{-1}$ \\
\hline $\mathrm{C}_{\mathrm{N}}$ & & & & & & & $\mathrm{C}_{\mathrm{N}}$ & & & & & & \\
\hline$\left(\mathrm{mg} \mathrm{L}^{-1}\right)$ & & & & & & & $\left(\mathrm{mg} \mathrm{L}^{-1}\right.$ & & & & & & \\
\hline 25 & & $0.80 \mathrm{~b}$ & $15.8 \mathrm{f}$ & $0.91 \mathrm{f}$ & $300.7 \mathrm{ab}$ & $17.1 \mathrm{bc}$ & 25 & & $0.47 \mathrm{a}$ & $42.4 \mathrm{e}$ & $0.55 \mathrm{e}$ & 391.6 & $5.24 \mathrm{ab}$ \\
\hline 50 & & $0.79 \mathrm{bc}$ & $33.8 \mathrm{e}$ & $1.94 \mathrm{e}$ & $304.5 \mathrm{ab}$ & $17.5 \mathrm{ab}$ & 45 & & $0.38 \mathrm{~b}$ & $83.5 \mathrm{~d}$ & $0.85 \mathrm{~d}$ & 397.1 & $4.31 \mathrm{~b}$ \\
\hline 75 & & $0.86 \mathrm{a}$ & $53.0 \mathrm{~d}$ & $3.31 \mathrm{~d}$ & $306.4 \mathrm{ab}$ & $18.9 \mathrm{a}$ & 65 & & $0.37 \mathrm{~b}$ & $96.3 \mathrm{~cd}$ & $1.01 \mathrm{~cd}$ & 416.0 & $4.40 \mathrm{~b}$ \\
\hline 100 & & $0.75 \mathrm{~cd}$ & $71.0 \mathrm{c}$ & $3.83 c$ & $297.4 \mathrm{~b}$ & $16.0 \mathrm{c}$ & 85 & & $0.38 \mathrm{~b}$ & $116.4 \mathrm{c}$ & $1.25 c$ & 424.3 & $4.60 \mathrm{~b}$ \\
\hline 125 & & $0.74 \mathrm{~d}$ & $93.3 \mathrm{~b}$ & $5.15 \mathrm{~b}$ & $311.4 \mathrm{a}$ & $17.3 \mathrm{bc}$ & 100 & & $0.39 \mathrm{~b}$ & $162.0 \mathrm{~b}$ & $1.83 \mathrm{~b}$ & 412.7 & $4.47 \mathrm{~b}$ \\
\hline 140 & & $0.77 \mathrm{bcd}$ & $107.2 \mathrm{a}$ & $5.96 \mathrm{a}$ & $306.7 \mathrm{ab}$ & $16.7 \mathrm{bc}$ & 125 & & $0.49 \mathrm{a}$ & $232.8 \mathrm{a}$ & $3.32 \mathrm{a}$ & 432.5 & $5.94 \mathrm{a}$ \\
\hline $\begin{array}{c}\mathrm{C}_{\mathrm{Cl}} \\
\left(\mathrm{mg} \mathrm{L}^{-1}\right)\end{array}$ & & & & & & & $\begin{array}{c}\mathrm{C}_{\mathrm{Cl}} \\
\left(\mathrm{mg} \mathrm{L}^{-1}\right.\end{array}$ & & & & & & \\
\hline 15 & & $0.80 \mathrm{a}$ & 61.8 & 3.50 & $20.2 \mathrm{~d}$ & $1.0 \mathrm{~d}$ & 15 & & $0.40 \mathrm{~b}$ & $117.7 \mathrm{~b}$ & $1.31 \mathrm{c}$ & $196.7 \mathrm{~d}$ & $2.17 \mathrm{c}$ \\
\hline 150 & & $0.79 \mathrm{ab}$ & 62.5 & 3.66 & 145.7 c & $8.5 \mathrm{c}$ & 150 & & $0.37 \mathrm{~b}$ & $111.8 \mathrm{~b}$ & $1.22 \mathrm{c}$ & $292.8 \mathrm{c}$ & $2.90 \mathrm{c}$ \\
\hline 350 & & $0.79 \mathrm{a}$ & 61.8 & 3.38 & $334.2 \mathrm{~b}$ & $18.7 \mathrm{~b}$ & 350 & & $0.44 \mathrm{a}$ & $115.7 \mathrm{~b}$ & $1.59 \mathrm{~b}$ & $433.5 \mathrm{~b}$ & $5.30 \mathrm{~b}$ \\
\hline 700 & & $0.76 \mathrm{~b}$ & 63.3 & 3.53 & 718.1 a & $40.3 \mathrm{a}$ & 700 & & $0.45 \mathrm{~b}$ & $143.8 \mathrm{a}$ & $1.79 \mathrm{a}$ & $726.3 \mathrm{a}$ & $8.94 \mathrm{a}$ \\
\hline variable & $\mathrm{df}$ & & Pro & ability of $F$ & lue & & variable & $\mathrm{df}$ & & & & & \\
\hline $\mathrm{C}_{\mathrm{N}}$ & 5 & $<0.0001$ & $<0.0001$ & $<0.0001$ & 0.0133 & 0.0079 & $C_{N}$ & 5 & $<0.0001$ & $<0.0001$ & $<0.0001$ & 0.786 & $<0.0001$ \\
\hline $\mathrm{C}_{\mathrm{Cl}}$ & 3 & 0.0041 & 0.1601 & 0.0476 & $<0.0001$ & $<0.0001$ & $\mathrm{C}_{\mathrm{Cl}}$ & 3 & $<0.0001$ & 0.0015 & $<0.0001$ & $<0.0001$ & $<.0001$ \\
\hline Block & 3 & 0.0866 & 0.0977 & 0.0559 & 0.9257 & 0.3459 & Block & 3 & 0.283 & 0.6966 & 0.6672 & 0.9923 & 0.4310 \\
\hline $\mathrm{C}_{\mathrm{N}}{ }^{*} \mathrm{C}_{\mathrm{Cl}}$ & 15 & $<0.0001$ & 0.3129 & 0.1582 & 0.4752 & 0.0839 & $\mathrm{C}_{\mathrm{N}}{ }^{*} \mathrm{C}_{\mathrm{Cl}}$ & 15 & $<.0001$ & 0.0011 & $<0.0001$ & $<0.0001$ & $<0.0001$ \\
\hline
\end{tabular}




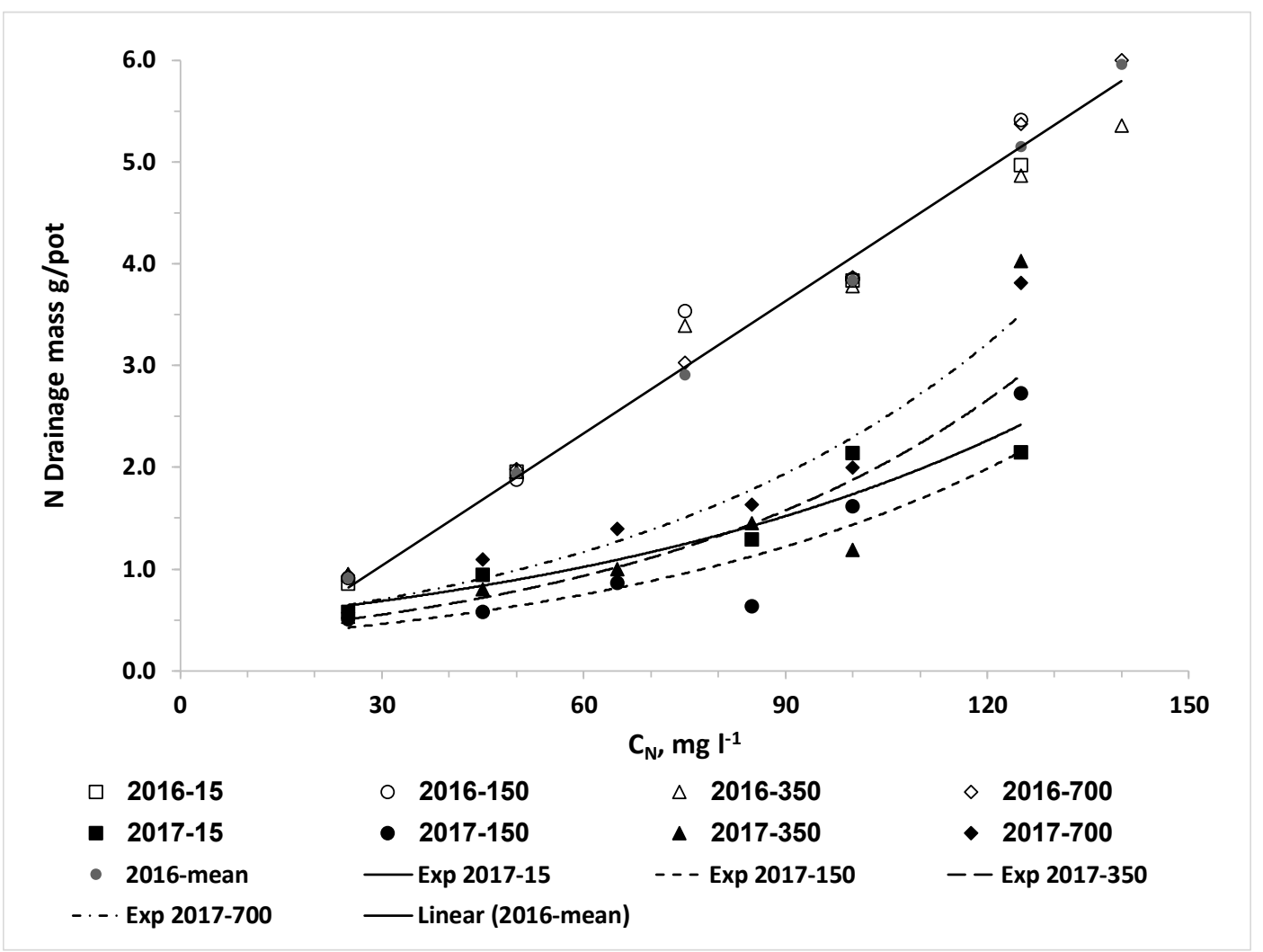

Figure 3. N mass in the leachate of lettuce experiments: 2016 and 2017. The equations of the best fit curves presented in Figure 3 are as follows: 2016, $C_{C l}=15, Y=0.4217 \mathrm{e}^{0.0137 \mathrm{X}}, \mathrm{R}^{2}=0.873 .2016$, $\mathrm{C}_{\mathrm{Cl}}=150, \mathrm{Y}=0.2834 \mathrm{e}^{0.0162 \mathrm{X}}, \mathrm{R}^{2}=0.803 .2016, \mathrm{C}_{\mathrm{Cl}}=300, \mathrm{Y}=0.3277 \mathrm{e}^{0.0174 \mathrm{X}}, \mathrm{R}^{2}=0.862 .2016, \mathrm{C}_{\mathrm{Cl}}=700$, $\mathrm{Y}=0.425 \mathrm{e}^{0.0169 \mathrm{X}}, \mathrm{R}^{2}=0.952$. 2017, Mean $\mathrm{C}_{\mathrm{Cl}}, \mathrm{Y}=0.0432 \mathrm{X}-0.261, \mathrm{R}^{2}=0.995$.

The drainage $\mathrm{Cl}$ concentration $\left(\mathrm{C}_{\mathrm{ClL}}\right)$ in both lettuce experiments increased with $\mathrm{C}_{\mathrm{Cl}}$, with significant differences between all $\mathrm{C}_{\mathrm{Cl}}$ levels (Table 8). Because of the much bigger LF in the first than the second lettuce experiment, the $\mathrm{C}_{\mathrm{ClL}}$ values in 2016 were slightly lower than the corresponding $\mathrm{C}_{\mathrm{Cl}}$, while the opposite was obtained in 2017. In 2016, $C_{N}$ had significant effect on $C_{C l L}$, but the change in $C_{C I L}$ as a function of $C_{N}$ was not consistent with clear trend, and in 2017 no significant effect of $C_{N}$ on $C_{C I L}$ was obtained. In 2016, there was no interactive effect of $C_{N}$ with $C_{C l}$ on $C_{C I L}$, while in 2017 there was interactive effect but the same trend of effect of $\mathrm{C}_{\mathrm{Cl}}$ on $\mathrm{C}_{\mathrm{ClL}}$ was obtained in all $\mathrm{C}_{\mathrm{N}}$ treatments. The drainage $\mathrm{Cl}$ mass $\left(\mathrm{M}_{\mathrm{ClL}}\right)$ in both lettuce experiments increased with $\mathrm{C}_{\mathrm{Cl}}$, with significant differences between all $\mathrm{C}_{\mathrm{Cl}}$ levels. Because of the much bigger $\mathrm{LF}$ in the first than the second lettuce experiment, the $\mathrm{M}_{\mathrm{CIL}}$ values in 2016 were greater than in 2017 (Table 8; Figure 4). In the two lettuce experiments, $\mathrm{C}_{N}$ had significant effect on $\mathrm{M}_{\mathrm{Cl} L}$, but the change in $\mathrm{M}_{\mathrm{ClL}}$ as a function of $\mathrm{C}_{\mathrm{N}}$, was not consistent with clear trend and it was much smaller than the effect of the $C_{C l}$. Significant interactive effect of $C_{N}$ with $\mathrm{C}_{\mathrm{Cl}}$ on $\mathrm{M}_{\mathrm{ClL}}$ was obtained in the second experiment, however the same trend of effect of $\mathrm{C}_{\mathrm{Cl}}$ on $\mathrm{M}_{\mathrm{ClL}}$ was obtained in all $\mathrm{C}_{\mathrm{N}}$ treatments. Overall, a linear increase of $\mathrm{M}_{\mathrm{ClL}}$ with raising $\mathrm{C}_{\mathrm{Cl}}$ was obtained in both years (Figure 4). 


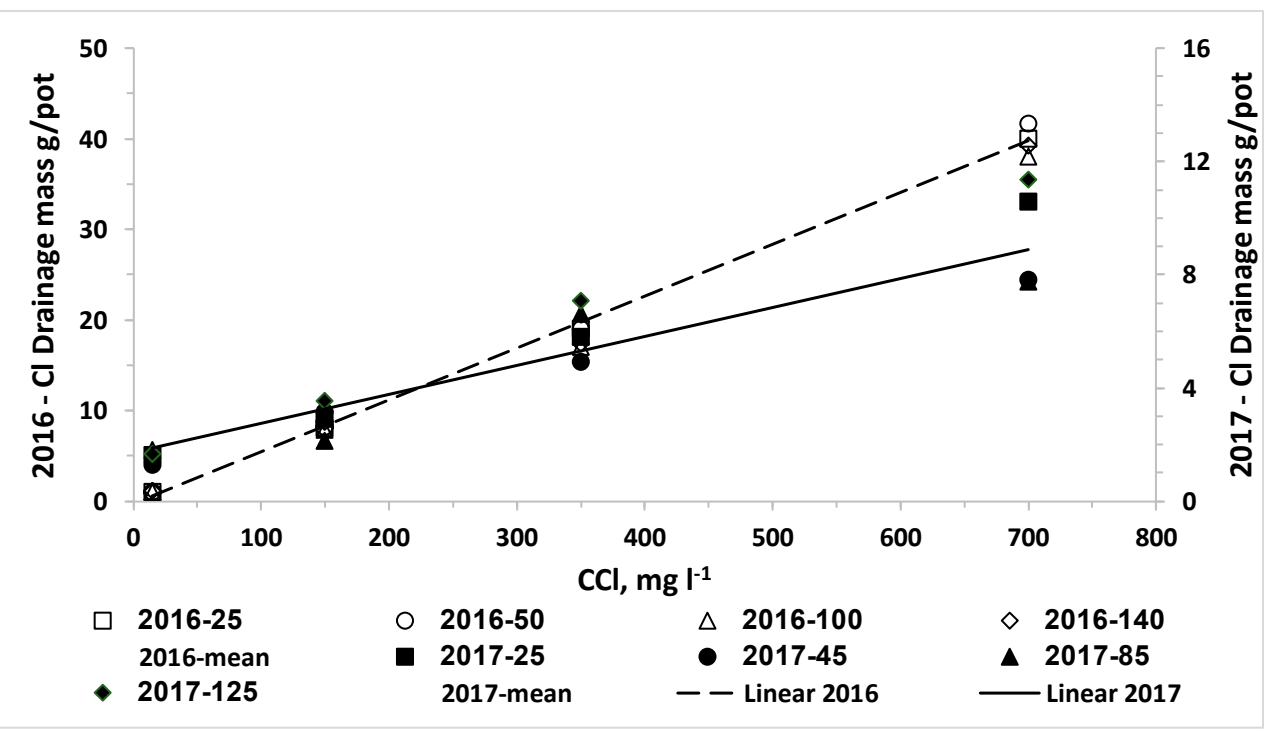

Figure 4. $\mathrm{Cl}$ mass in the leachate of lettuce experiments, 2016 and 2017. The equations of best fit curves presented in Figure 4 are as follows: 2016, $\mathrm{Y}=0.057 \mathrm{X}-0.2646, \mathrm{R}^{2}=0.998 .2017, \mathrm{Y}=0.010 \mathrm{X}+1.73$, $\mathrm{R}^{2}=0.992$.

\subsubsection{Leaching Fraction and Leachate Composition in the Potato Experiments}

Similar to the lettuce experiments, in the three potato experiments the LF was relatively high, above 0.45 , due to the excess irrigation in the coarse sand to maintain available water for plants and to obtain drainage for monitoring water composition in the growth medium. In the three experiments, LF decreased considerably and significantly with increasing the $C_{N}$ (Table 9a). In the first experiment, $C_{C L}$ had no effect on LF and no interaction of $C_{N}$ with $C_{C L}$ was obtained. In the second and third experiments, the LF significantly increased as the $\mathrm{C}_{\mathrm{Cl}}$ increased; a mirror of the effect of $\mathrm{C}_{\mathrm{Cl}}$ on the biomass production. An interactive effect of $C_{N}$ with $C_{C L}$ was obtained in the third experiment, due to the different effect of $C_{C l}$ on $L F$ in the lowest $C_{N}$ value than in the other $C_{N}$ treatments. This difference is probably a result of the strong and dominant negative effect of the lowest $C_{N}$ treatment on biomass production and transpiration.

In the three potato experiments, $C_{N L}$ increased significantly with raising $C_{N}$ with no effect of $C_{C l}$ and no interactive effect of $C_{N}$ with $C_{C l}$ (Table $9 a$ ). The values of $C_{N L}$ were lower than the corresponding $C_{N}$ in the first experiment, whereas similar and higher values were obtained in the third and second experiments, respectively. The $\mathrm{M}_{\mathrm{NL}}$ was also significantly increased with raising $\mathrm{C}_{\mathrm{N}}$ in all three potato experiments (Table $9 \mathrm{a}$ and Figure 5). No effect of $\mathrm{C}_{\mathrm{Cl}}$ and no interaction of $\mathrm{C}_{\mathrm{N}}$ with $\mathrm{C}_{\mathrm{Cl}}$ were observed in the first experiment, whereas a significant increase of $\mathrm{M}_{\mathrm{NL}}$ with increasing $\mathrm{C}_{\mathrm{Cl}}$ and interactive effect of $C_{N}$ with $C_{C l}$ was observed in the second and third experiments due to difference in the strength but not the trend of the effect of $C_{N}$ on $M_{N L}$ at each $C_{C l}$ level (Table $9 a$ and Figure 5). The effect of $\mathrm{C}_{\mathrm{Cl}}$ on $\mathrm{M}_{\mathrm{NL}}$ in the second and third experiments is probably due to the increase in the $\mathrm{LF}$ with $\mathrm{C}_{\mathrm{Cl}}$, as no effect of $\mathrm{C}_{\mathrm{Cl}}$ on $\mathrm{C}_{\mathrm{NL}}$ was observed. In the three experiments, a nonlinear effect of $\mathrm{C}_{\mathrm{N}}$ on $\mathrm{M}_{\mathrm{NL}}$ was observed. In 2016, the predictions of $\mathrm{M}_{\mathrm{NL}}$ as function of $\mathrm{C}_{\mathrm{N}}$ by the exponential model were very close to the measured values, whereas in 2017 and 2018 the predictions of the exponential model underestimated $\mathrm{N}$ drainage mass of at $C_{N} 100 \mathrm{mg} \mathrm{L}^{-1}$ and overestimated it at $C_{N} 150 \mathrm{mg} \mathrm{L}^{-1}$ (Figure 5). Nevertheless, in all three years the slope became steeper as $C_{N}$ was raised above $40 \mathrm{mg} \mathrm{L}^{-1}$. 
Table 9. The effects of $\mathrm{C}_{\mathrm{N}}$ and $\mathrm{C}_{\mathrm{Cl}}$ on (a) leaching fraction (LF) and the concentrations and mass of $\mathrm{N}$ in the leachate $\left(\mathrm{C}_{\mathrm{NL}}\right.$ and $\left.\mathrm{M}_{\mathrm{NL}}\right)$, and (b) the concentrations and the mass of $\mathrm{Cl}$ in the leachate $\left(\mathrm{C}_{\mathrm{ClL}}\right.$ and $\left.\mathrm{M}_{\mathrm{ClL}}\right)$ in the potato experiments. The probability of $F$ values for $\mathrm{C}_{\mathrm{N}}, \mathrm{C}_{\mathrm{Cl}}$, block factors, and the interaction of $\mathrm{C}_{\mathrm{N}}$ and $\mathrm{C}_{\mathrm{Cl}}$ was determined using the two-way ANOVA procedure of JMP 14. Different letters on the right side of values indicate significant difference between treatments (HSD) at $p$ $<0.05$ by the Tukey-Kramer honestly test. No letters are presented when no significant difference was obtained.

\begin{tabular}{|c|c|c|c|c|c|c|c|c|c|c|c|c|c|c|}
\hline \multicolumn{15}{|c|}{ (a) Leaching fraction (LF), the Concentrations and Mass of $N$ in the Leachate $\left(\mathrm{C}_{\mathrm{NL}}\right.$ and $\left.\mathrm{M}_{\mathrm{NL}}\right)$. } \\
\hline \multicolumn{5}{|c|}{2016} & \multicolumn{5}{|c|}{2017} & \multicolumn{5}{|c|}{2018} \\
\hline Variable & & LF & $\mathrm{C}_{\mathrm{NL}}$ & $\mathbf{M}_{\mathrm{NL}}$ & Variable & & LF & $\mathrm{C}_{\mathrm{NL}}$ & $\mathbf{M}_{\mathrm{NL}}$ & Variable & & LF & $\mathrm{C}_{\mathrm{NL}}$ & $\mathbf{M}_{\mathrm{NL}}$ \\
\hline & & & $\mathrm{mg} \mathrm{L}^{-1}$ & $\mathrm{~g} \mathrm{pot}^{-1}$ & & & & $\mathrm{mg} \mathrm{L}^{-1}$ & $\mathrm{~g} \mathrm{pot}^{-1}$ & & & & $\mathrm{mg} \mathrm{L}^{-1}$ & $\mathrm{~g} \mathrm{pot}^{-1}$ \\
\hline $\mathrm{C}_{\mathrm{N}}$ & & & & & $\mathrm{C}_{\mathrm{N}}$ & & & & & $\mathrm{C}_{\mathrm{N}}$ & & & & \\
\hline $\mathrm{mg} \mathrm{L}^{-1}$ & & & & & $\mathrm{mg} \mathrm{L}^{-1}$ & & & & & $\mathrm{mg} \mathrm{L}^{-1}$ & & & & \\
\hline 10 & & $0.86 \mathrm{a}$ & $9.1 \mathrm{e}$ & $1.31 \mathrm{~d}$ & 10 & & $0.66 \mathrm{a}$ & $8.8 \mathrm{~d}$ & $0.71 \mathrm{~d}$ & 10 & & $0.79 \mathrm{a}$ & $9.7 \mathrm{~d}$ & $0.82 \mathrm{~d}$ \\
\hline 20 & & $0.82 \mathrm{~b}$ & $10.5 \mathrm{de}$ & $1.42 \mathrm{~cd}$ & 50 & & $0.50 \mathrm{~b}$ & $69.1 \mathrm{c}$ & $0.43 c$ & 50 & & $0.70 \mathrm{~b}$ & $35.7 \mathrm{c}$ & $2.80 \mathrm{c}$ \\
\hline 30 & & $0.77 \mathrm{c}$ & $12.2 \mathrm{~cd}$ & $1.53 \mathrm{~cd}$ & 100 & & $0.50 \mathrm{~b}$ & $210.5 \mathrm{~b}$ & $1.26 \mathrm{~b}$ & 100 & & $0.68 \mathrm{~b}$ & $114.4 \mathrm{~b}$ & $8.40 \mathrm{~b}$ \\
\hline 40 & & $0.73 c$ & $14.0 \mathrm{c}$ & $1.65 \mathrm{c}$ & 150 & & $0.47 \mathrm{~b}$ & 315.9 a & $1.73 \mathrm{a}$ & 150 & & $0.57 \mathrm{c}$ & 186.9 a & $11.49 \mathrm{a}$ \\
\hline 60 & & $0.66 \mathrm{~d}$ & $22.5 \mathrm{~b}$ & $2.39 \mathrm{~b}$ & & & & & & & & & & \\
\hline 80 & & $0.60 \mathrm{e}$ & $30.6 \mathrm{a}$ & $2.96 \mathrm{a}$ & & & & & & & & & & \\
\hline $\begin{array}{c}\mathrm{C}_{\mathrm{Cl}} \\
\mathrm{mg} \mathrm{L}^{-1}\end{array}$ & & & & & $\begin{array}{c}\mathrm{C}_{\mathrm{Cl}} \\
\mathrm{mg} \mathrm{L}^{-1}\end{array}$ & & & & & $\begin{array}{c}\mathrm{C}_{\mathrm{Cl}} \\
\mathrm{mg} \mathrm{L}^{-1}\end{array}$ & & & & \\
\hline 15 & & 0.76 & 16.6 & 1.94 & 15 & & $0.51 \mathrm{ab}$ & 151.2 & $7.90 \mathrm{ab}$ & 15 & & $0.59 \mathrm{c}$ & 84.9 & $4.44 \mathrm{~d}$ \\
\hline 150 & & 0.73 & 16.0 & 1.81 & 150 & & $0.46 \mathrm{~b}$ & 149.6 & $7.54 b$ & 200 & & $0.61 \mathrm{c}$ & 88.2 & $5.11 \mathrm{~cd}$ \\
\hline 350 & & 0.73 & 16.6 & 1.88 & 350 & & $0.55 \mathrm{ab}$ & 155.0 & $9.59 \mathrm{a}$ & 600 & & $0.69 \mathrm{~b}$ & 80.1 & $5.64 \mathrm{bc}$ \\
\hline 700 & & 0.74 & 16.7 & 1.87 & 700 & & $0.60 \mathrm{a}$ & 148.5 & $9.88 \mathrm{a}$ & 1100 & & $0.75 \mathrm{ab}$ & 87.0 & $6.78 \mathrm{ab}$ \\
\hline variable & $\mathrm{df}$ & & & & variable & $\mathrm{df}$ & & & & $\begin{array}{c}1500 \\
\text { variable }\end{array}$ & $\mathrm{df}$ & $0.78 \mathrm{a}$ & 93.1 & $7.43 \mathrm{a}$ \\
\hline $\mathrm{C}_{\mathrm{N}}$ & 5 & $<0.0001$ & $<0.0001$ & $<0.0001$ & $\mathrm{C}_{\mathrm{N}}$ & 3 & $<0.0001$ & $<0.0001$ & $<0.0001$ & $\mathrm{C}_{\mathrm{N}}$ & 3 & $<0.0001$ & 0.1859 & $<0.0001$ \\
\hline $\mathrm{C}_{\mathrm{Cl}}$ & 3 & 0.0970 & 0.5740 & 0.4756 & $\mathrm{C}_{\mathrm{Cl}}$ & 3 & 0.0018 & 0.8441 & 0.0057 & $\mathrm{C}_{\mathrm{Cl}}$ & 4 & $<0.0001$ & $<0.0001$ & $<0.0001$ \\
\hline Block & 3 & 0.2997 & 0.1780 & 0.0797 & Block & 3 & 0.4976 & 0.2018 & 0.4815 & Block & 3 & 0.2711 & 0.2400 & 0.3673 \\
\hline $\mathrm{C}_{\mathrm{N}}{ }^{*} \mathrm{C}_{\mathrm{Cl}}$ & 15 & 0.3554 & 0.9515 & 0.9907 & $\mathrm{C}_{\mathrm{N}} * \mathrm{C}_{\mathrm{Cl}}$ & 9 & 0.0733 & 0.1841 & 0.0403 & $\mathrm{C}_{\mathrm{N}}{ }^{*} \mathrm{C}_{\mathrm{Cl}}$ & 12 & $<0.0001$ & 0.4624 & 0.0109 \\
\hline
\end{tabular}


Table 9. Cont.

\begin{tabular}{|c|c|c|c|c|c|c|c|c|c|c|c|}
\hline \multicolumn{4}{|c|}{2016} & \multicolumn{4}{|c|}{2017} & \multicolumn{4}{|c|}{2018} \\
\hline Variable & & $\mathrm{C}_{\mathrm{ClL}}$ & $\mathbf{M}_{\mathrm{ClL}}$ & Variable & & $\mathrm{C}_{\mathrm{ClL}}$ & $\mathbf{M}_{\mathrm{ClL}}$ & Variable & & $\mathrm{C}_{\mathrm{CIL}}$ & $\mathbf{M}_{\mathrm{ClL}}$ \\
\hline & & $\mathrm{mg} \mathrm{L}^{-1}$ & $\mathrm{~g} \mathrm{pot}^{-1}$ & & & $\mathrm{mg} \mathrm{L}^{-1}$ & $\mathrm{~g} \mathrm{pot}^{-1}$ & & & $\mathrm{mg} \mathrm{L}^{-1}$ & $\mathrm{~g}$ pot $^{-1}$ \\
\hline $\mathrm{C}_{\mathrm{N}}$ & & & & $\mathrm{C}_{\mathrm{N}}$ & & & & $\mathrm{C}_{\mathrm{N}}$ & & & \\
\hline $\mathrm{mg} \mathrm{L}^{-1}$ & & & & $\mathrm{mg} \mathrm{L}^{-1}$ & & & & $\mathrm{mg} \mathrm{L}^{-1}$ & & & \\
\hline 10 & & $282 \mathrm{e}$ & $40.4 \mathrm{a}$ & 10 & & $390 \mathrm{~b}$ & 31.5 & 10 & & $794 \mathrm{~b}$ & $66.0 \mathrm{~b}$ \\
\hline 20 & & 290 de & $38.5 \mathrm{ab}$ & 50 & & $490 \mathrm{a}$ & 31.2 & 50 & & 894 a & $74.0 \mathrm{a}$ \\
\hline 30 & & $306 \mathrm{~cd}$ & $38.3 \mathrm{ab}$ & 100 & & $522 \mathrm{a}$ & 30.5 & 100 & & $953 a$ & $78.5 \mathrm{a}$ \\
\hline 40 & & 318 bc & $36.6 \mathrm{~b}$ & 150 & & 529 a & 32.2 & 150 & & $961 \mathrm{a}$ & $64.0 \mathrm{~b}$ \\
\hline 60 & & $339 \mathrm{~b}$ & $36.0 \mathrm{~b}$ & & & & & & & & \\
\hline 80 & & 3851 a & $36.4 \mathrm{~b}$ & & & & & & & & \\
\hline $\begin{array}{c}\mathrm{C}_{\mathrm{Cl}} \\
\mathrm{mg} \mathrm{L}^{-1}\end{array}$ & & & & $\begin{array}{c}\mathrm{C}_{\mathrm{Cl}} \\
\mathrm{mg} \mathrm{L}^{-1}\end{array}$ & & & & $\begin{array}{c}\mathrm{C}_{\mathrm{Cl}} \\
\mathrm{mg} \mathrm{L}^{-1}\end{array}$ & & & \\
\hline 15 & & $21 \mathrm{~d}$ & $2.6 \mathrm{~d}$ & 15 & & $147 \mathrm{~d}$ & $8.5 \mathrm{~d}$ & 15 & & $137 \mathrm{e}$ & $7.9 \mathrm{e}$ \\
\hline 150 & & $139 c$ & $16.6 c$ & 150 & & $324 \mathrm{c}$ & $17.5 \mathrm{c}$ & 200 & & $396 \mathrm{~d}$ & $25.4 \mathrm{~d}$ \\
\hline 350 & & $351 \mathrm{~b}$ & $41.8 \mathrm{~b}$ & 350 & & $512 \mathrm{~b}$ & $32.7 \mathrm{~b}$ & 600 & & 847 c & $62.8 \mathrm{c}$ \\
\hline 700 & & 768 a & $89.8 \mathrm{a}$ & 700 & & 949 a & $66.7 \mathrm{a}$ & 1100 & & 1333 b & $107.5 \mathrm{~b}$ \\
\hline variable & $\mathrm{df}$ & & & variable & $\mathrm{df}$ & & & $\begin{array}{c}1500 \\
\text { variable }\end{array}$ & $\mathrm{df}$ & 1790 a & $149.5 \mathrm{a}$ \\
\hline $\mathrm{C}_{\mathrm{N}}$ & 5 & $<0.0001$ & $<0.0001$ & $\mathrm{C}_{\mathrm{N}}$ & 3 & $<0.0001$ & 0.7444 & $\mathrm{C}_{\mathrm{N}}$ & 3 & $<0.0001$ & $<0.0001$ \\
\hline $\mathrm{C}_{\mathrm{Cl}}$ & 3 & $<0.0001$ & $<0.0001$ & $\mathrm{C}_{\mathrm{Cl}}$ & 3 & $<0.0001$ & $<0.0001$ & $\mathrm{C}_{\mathrm{Cl}}$ & 4 & $<0.0001$ & $<0.0001$ \\
\hline Block & 3 & 0.8437 & 0.8732 & Block & 3 & 0.3187 & 0.5949 & Block & 3 & 0.0262 & 0.3923 \\
\hline $\mathrm{C}_{\mathrm{N}}{ }^{*} \mathrm{C}_{\mathrm{Cl}}$ & 15 & $<0.0001$ & 0.1934 & $\mathrm{C}_{\mathrm{N}}{ }^{*} \mathrm{C}_{\mathrm{Cl}}$ & 9 & 0.0503 & 0.0002 & $\mathrm{C}_{\mathrm{N}} * \mathrm{C}_{\mathrm{Cl}}$ & 12 & 0.0020 & $<0.0001$ \\
\hline
\end{tabular}




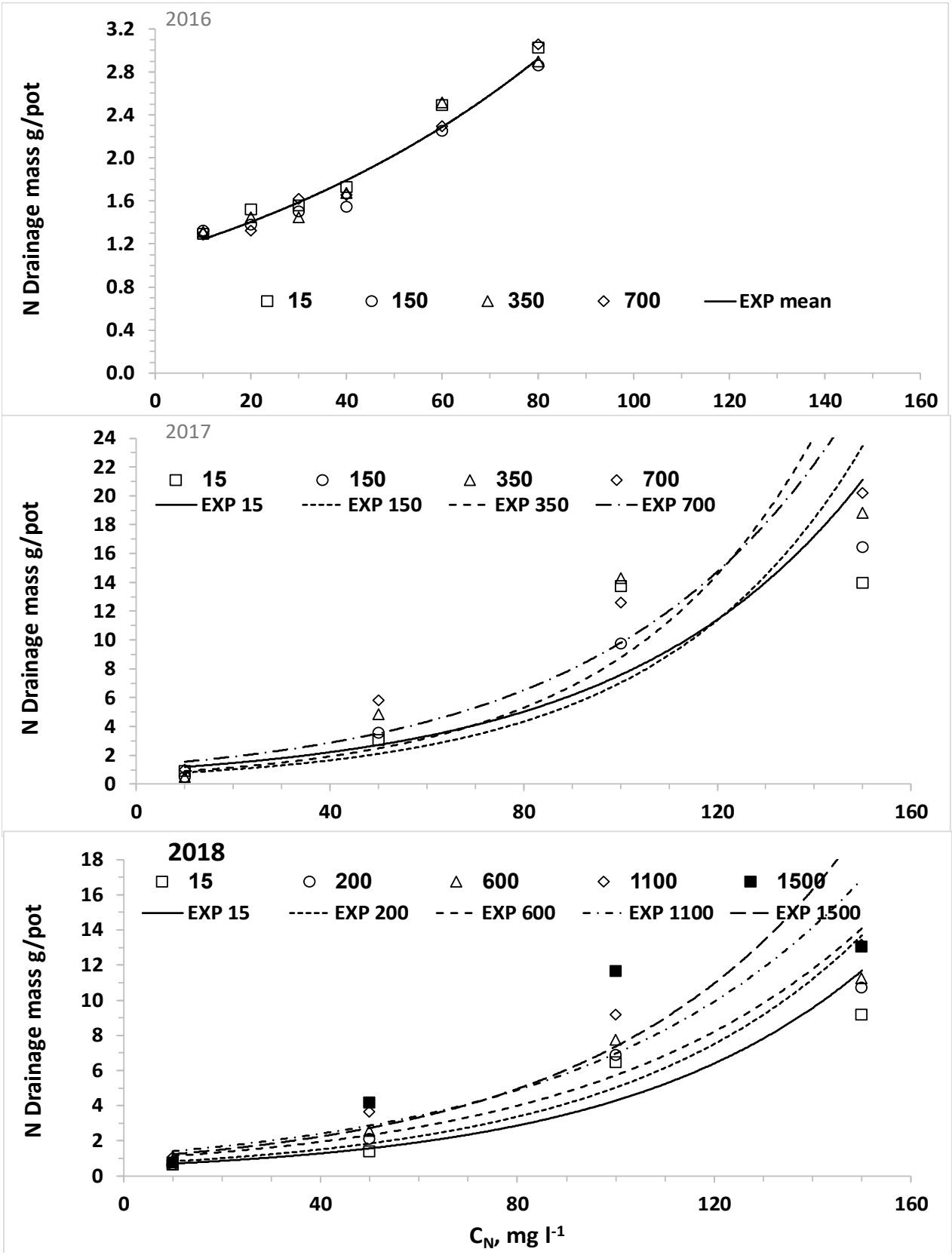

Figure 5. Nitrogen mass in the leachate of three potato experiments: 2016,2017, and 2018. The equations of best fit curves of $\mathrm{N}$-Drainage mass $\left(\mathrm{M}_{\mathrm{NL}}\right)$ vs. $\mathrm{N}$ irrigation concentration $\left(\mathrm{C}_{\mathrm{N}}\right)$ are presented in Figure 5 as follows: 2016, mean, $\mathrm{Y}=1.1008 \mathrm{e} 0.0122 \mathrm{x}, \mathrm{R} 2=0.975 .2017,15, \mathrm{Y}=0.9752 \mathrm{e} 0.0205 \mathrm{x}, \mathrm{R} 2=0.882$. 2017, 150, $\mathrm{Y}=0.631 \mathrm{e} 0.0241 \mathrm{x}, \mathrm{R} 2=0.896 .2017,350, \mathrm{Y}=0.7004 \mathrm{e} 0.0253 \mathrm{x}, \mathrm{R} 2=0.839 .2017,700$, $\mathrm{Y}=1.2692 \mathrm{e} 0.0204 \mathrm{x}, \mathrm{R} 2=0.887 .2018,15, \mathrm{Y}=0.5781 \mathrm{e} 0.02 \mathrm{x}, \mathrm{R} 2=0.948 .2018,200, \mathrm{Y}=0.6808 \mathrm{e} 0.02 \mathrm{x}$, $\mathrm{R} 2=0.952 .2018,600, \mathrm{Y}=0.9483 \mathrm{e} 0.018 \mathrm{x}, \mathrm{R} 2=0.951 .2018,1100, \mathrm{Y}=1.1867 \mathrm{e} 0.0177 \mathrm{x}, \mathrm{R} 2=0.927 .2018$, $1500, \mathrm{Y}=1.1015 \mathrm{e} 0.0198 \mathrm{x}, \mathrm{R} 2=0.927$.

In all three potato experiments the $\mathrm{C}_{\mathrm{ClL}}$ was significantly affected by $\mathrm{C}_{\mathrm{Cl}}$ and $\mathrm{C}_{\mathrm{N}}$, and also the interactive effect of these factors was obtained (Table $9 b$ ). However, in all three experiments the relative effect of $\mathrm{C}_{\mathrm{Cl}}$ on $\mathrm{C}_{\mathrm{ClL}}$ is much bigger than that of $\mathrm{C}_{\mathrm{N}}$ and the interactive effect is due to small differences in the relative effect of $\mathrm{C}_{\mathrm{Cl}}$ at different $\mathrm{C}_{\mathrm{N}}$ values, but no difference in the trend of the effect was obtained, therefore the overall main effects are further discussed. $\mathrm{C}_{\mathrm{ClL}}$ increased linearly with $\mathrm{C}_{\mathrm{Cl}}$ in the three experiments with the following slopes; 1.01, 1.156, and 1.09 in the first, second, and the third experiment, respectively. In all three experiments, $C_{C l L}$ increased linearly with $C_{N}$ (Table $9 b$ ) as a result 
of the decreased LF with inncreasing $\mathrm{CN}$ as shown above. In all three experiments, $\mathrm{M}_{\mathrm{ClL}}$ increased considerably and significantly with raising the $C_{C l}$, whereas $C_{N}$ had no considerable effect. In the first experiment, there was no interactive effect of $C_{C l}$ with $C_{N}$, whereas a significant interactive effect was obtained in the second and third experiments. Despite the interactive effect of $\mathrm{C}_{\mathrm{Cl}}$ with $\mathrm{C}_{\mathrm{N}}$ in two of the experiments, the same trend of increasing $\mathrm{M}_{\mathrm{Cl}}$ with $\mathrm{C}_{\mathrm{Cl}}$ was obtained at all $\mathrm{CN}$ levels in the three experiments. In all three experiments, $\mathrm{M}_{\mathrm{ClL}}$ increased linearly with $\mathrm{C}_{\mathrm{Cl}}$ with slopes in the range of 0.086 to $0.128 \mathrm{~g} \mathrm{Cl} / \mathrm{pot} /\left(\mathrm{mg} \mathrm{Cl} / \mathrm{L}\right.$ ) (Figure 6). Unlike the relation of $\mathrm{M}_{\mathrm{NL}}$ with $\mathrm{C}_{\mathrm{N}}$, there is no a threshold $\mathrm{C}_{\mathrm{Cl}}$ point above which there is steeper increase of $\mathrm{M}_{\mathrm{ClL}}$ with further increase in $\mathrm{C}_{\mathrm{Cl}}$.

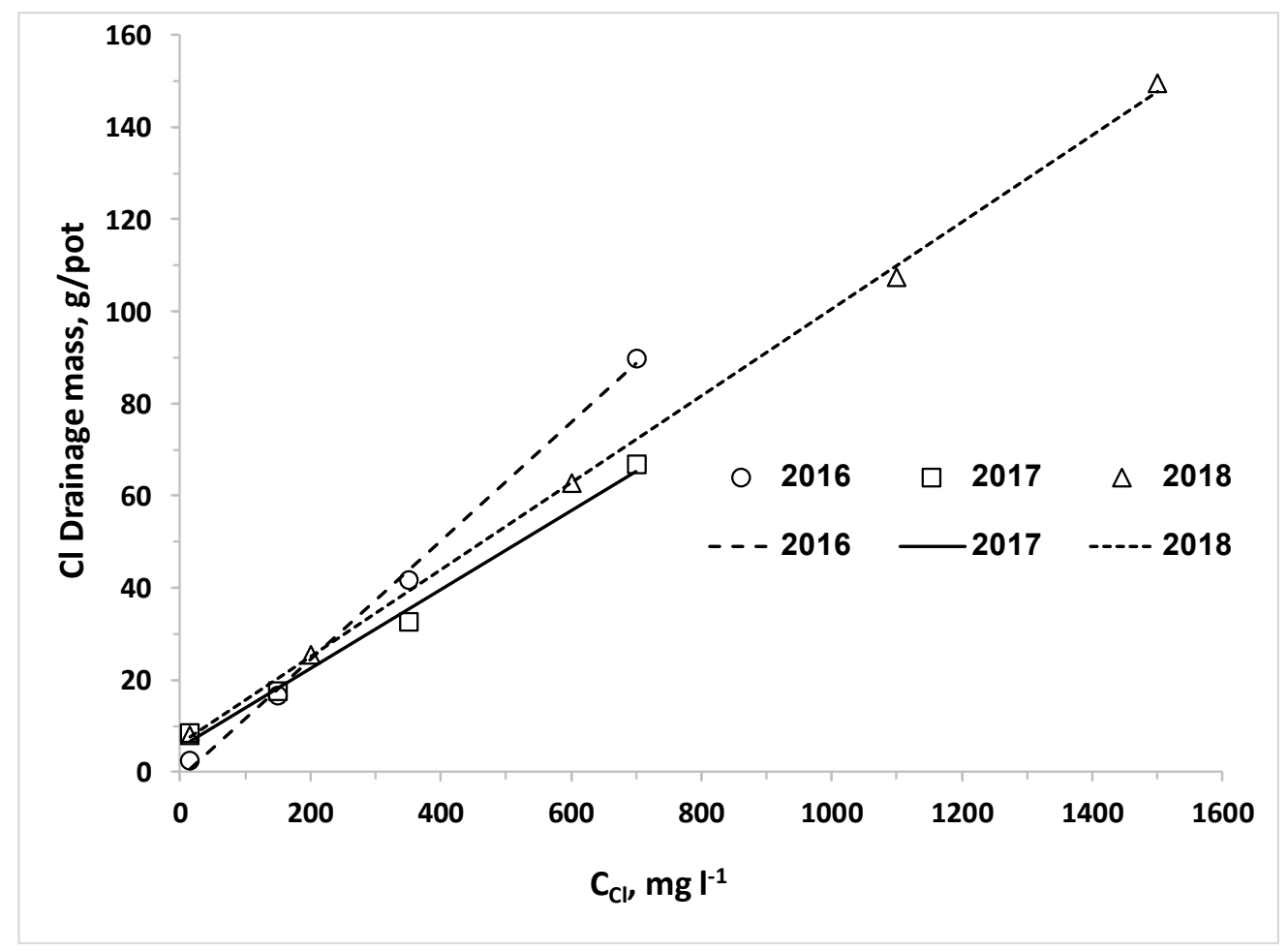

Figure 6. $\mathrm{M}_{\mathrm{Cl}}$ as function of $\mathrm{C}_{\mathrm{Cl}}$ in three potato experiments: 2016, 2017, and 2018. The equations of best fit curves of $\mathrm{Cl}$-Drainage mass $\left(\mathrm{M}_{\mathrm{ClL}}\right)$ vs. $\mathrm{Cl}$ irrigation concentration $\left(\mathrm{C}_{\mathrm{Cl}}\right)$ are presented in Figure 5 are as follows: $2016, \mathrm{Y}=0.1285 \mathrm{X}-1.34, \mathrm{R} 2=0.998 .2017, \mathrm{Y}=0.086 \mathrm{X}+5.33, \mathrm{R} 2=0.998 .2018$, $\mathrm{Y}=0.0944 \mathrm{X}+6.15, \mathrm{R} 2=0.999$.

\section{Discussion}

The main hypothesis of this research was that the optimal nitrogen concentration for the highest yield will be lower with decreasing chloride concentration of the irrigating solution. Therefore, we hypothesized that lower nitrogen concentrations will be required with desalinated water for achieving maximum yield. However, the opposite results were obtained in the current experiment with two crops: lettuce and potato. Using the best fit response curves of lettuce heads (quadratic equation) and potato tubers (Mitcherlich model) we found that higher values of $C_{N}$ were required for obtaining the maximal yield with desalinated or moderate salinity (low chloride concentrations) than for irrigation with high salinity water (high chloride concentrations). However, one should note that the maximum yields under desalinated or moderate salinity were bigger than under high salinity water. Extending the scope of the research from the question of the opportunity to reduce nitrogen fertilization with the use of desalinated water to the wider question of the possible interaction of salinity with fertilization, several published studies showed interactions of nitrogen with chloride in avocado [22], tomato [16-19], and melon [17], whereas other studies found no interaction in maize [37], pepper [38], and various horticultural crops [39]. 
The hypothesis of the possible interaction of $\mathrm{C}_{\mathrm{N}}$ with $\mathrm{C}_{\mathrm{Cl}}$ leading to the opportunity to reduce the recommended $C_{N}$ with desalinated water is based on findings on competition between the ions chloride and nitrate in uptake by plants [14,16-18]. Our assumptions were (i) the uptake and the concentration of chloride in organs of plants will be reduced by elevating $C_{N}$ and (ii) the uptake of and the concentration of nitrogen in organs of plants irrigated with desalinated water will be higher than in plants irrigated with higher chloride concentrations when the same $C_{N}$ is applied. As expected, we also found that the concentration of chloride in plant organs of lettuce and potato decreased with elevating the $C_{N}$ (Tables 6 and 7). However, no effect of $C_{C l}$ on the concentrations of reduced nitrogen in plant organs was found in lettuce and potato (Tables 6 and 7), in agreement with published findings for pepper [38]. On the other hand, nitrate concentration in lettuce and potato leaves decreased with increasing $\mathrm{C}_{\mathrm{Cl}}$, but this reduction had negligible impact on the total content of nitrogen in plants organs, because the reduced nitrogen is the main component of nitrogen in plant organs.

The response of plants biomass production to nitrogen is dependent of environmental conditions including salinity. Following Liebig's law of the minimum, when water of low salinity, like desalinated water, is used, the potential for high biomass production is elevated and the demand for nitrogen is higher. Therefore, the optimal $C_{N}$ for fertigation with desalinated water or another water source with low salinity and chloride concentration is higher or the same than the concentration recommended with other fresh water with relative low salinity. When the irrigating water containing high chloride concentration the salinity leads to reduction in the potential biomass and the demand for nitrogen, consequently in most investigations there was no positive effect of elevating $C_{N}$ with saline water irrigation. The negative effect of high salinity on plant biomass is caused by two main factors: (i) osmotic effect on water uptake and (ii) specific toxic effects of ions. Elevating $C_{N}$ as well as other nutrients is useless as a mitigating tool against the negative effect of the osmotic pressure; moreover, the elevated concentrations of nutrients contribute to higher osmotic pressure. Consequently, in many studies no positive effect of elevating nutrients concentrations above the recommended levels with fresh water were observed $[18,37,38]$. The few cases where positive effects of elevating nutrients concentrations applied with saline water above the optimal concentration for plants irrigated with low salinity water were probably obtained with plants that are highly sensitive to specific toxic effects of some ions, especially $\mathrm{Cl}$ and $\mathrm{Na}[13,22,40]$. In the current research with both lettuce and potato, which are defined as moderately salt-sensitive [6,7], the major impact of the high chloride treatments was probably the total salinity affecting the osmotic pressure and the required energy for water uptake. In such crops the optimal required nitrogen is not higher in high salinity and chloride solutions.

Several reviews concluded that the results reported in the literature on the interaction between salinity and nutrients were contradictory or indicated no interactive effects [10,15,37,39,41]. Grattan and Grieve (1999) [39] concluded that "Despite a large number of studies that demonstrate that salinity reduces nutrient uptake and accumulation or affects nutrient partitioning within the plant, little evidence exists that adding nutrients at levels above what is considered optimal in non-saline environments, improves crop yield." Recently, it was reported that nitrogen doses beyond the recommended values exacerbated the negative effects of salinity on growth and photosynthetic rates, in maize and cotton plants growing under moderate to high salinity conditions [42]. They found that the negative effect of high salinity with high dose of nitrogen was stronger in maize which is less tolerant to salinity.

However, part of this conflict can be removed by using the Bernstein definitions [43] of three different types of idealized salinity/nutrition interactions: (a) increased salt tolerance at suboptimal nutritional levels, (b) independent effects of salinity and nutrition at optimal and suboptimal nutritional levels, and (c) decreased salt tolerance at suboptimal nutritional levels. This method requires several salinity levels at each fertilization level. In the current research just in the third potato experiment there were more than four concentrations of $\mathrm{C}_{\mathrm{Cl}}$ (salinity level) and in that experiment we found that the slope of reduction in yield as a function of $\mathrm{C}_{\mathrm{Cl}}$ was not affected by the $\mathrm{C}_{\mathrm{N}}$ (type $\mathrm{b}$ case in Bernstein model).

We also set the hypothesis that the uptake of water and nitrogen of plants irrigated with desalinated water will be higher than that of plants irrigated with water containing higher chloride concentrations; 
consequently, the LF and the downward leaching of chloride and nitrate below the root zone will be reduced by irrigation with desalinated water. The results of the current research approved this hypothesis for both crops when the irrigation volume was the same for all combinations of $\mathrm{C}_{\mathrm{N}}$ and $\mathrm{C}_{\mathrm{Cl}}$. In reality, the optimal management of irrigation with water sources with different salinity levels should be adjusted to minimize the salinity in and below the root zone. Therefore, the required volume and LF of irrigating water decrease as the salinity decreases and thus the lowest water volume is required when plants are irrigated with desalinated water. Consequently, the efficiency of the applied nitrogen is higher and the total amount of applied nitrogen with desalinated water might be lower despite the higher $C_{N}$ of the fertigation. We expected that the use of desalinated water will enhance plant biomass and water uptake and reduce the LF over water of moderate salinity. However, in most of the lettuce and potato experiments in the current study there was no advantage to desalinated water over the treatment of low $\mathrm{C}_{\mathrm{Cl}}$ in the range of 100 to $200 \mathrm{mg} \mathrm{L}^{-1}$. It should be noted that the response of the plants is to the effective salinity, in the root zone, rather than the salinity of the irrigated water. The LF in irrigation of commercial fields and in most experiments is much lower than the LF values in the current experiments. Therefore, the effective salinity or $\mathrm{Cl}$ concentration in the soil solution in commercial fields is several times higher than that of the irrigation water, while in the current research the $\mathrm{Cl}$ concentration of the drainage was similar or just two times higher than $\mathrm{C}_{\mathrm{Cl}}$. Therefore, we suggest that in real life the enhancement of biomass production and reduction in LF and downward leaching of nitrate and chloride by a shift from moderate salinity to desalinated water will be bigger than in the current study.

The nonlinear increase of $C_{N L}$ and $M_{N L}$ as a function of $C_{N}$ with steep increase above a threshold that was obtained in all potato experiments is in agreement with our previous study [44]. This result is typical of the reduced efficiency of $\mathrm{N}$ uptake with increased $\mathrm{C}_{\mathrm{N}}$, which is quantitatively described by nutrient uptake models like the Michalis-Menten equation [14]. In part of the experiments, elevating $\mathrm{C}_{\mathrm{CL}}$ level increased significantly $\mathrm{M}_{\mathrm{NL}}$ as a result of the smaller biomass production and higher $\mathrm{LF}$. Although the LF values in the current experiments were much higher than those in commercial fields, the general trend of higher leaching fraction with higher salinity is also practiced in commercial fields to prevent salts accumulation in the root-zone [27,28,35,41]. Thus, reduced $\mathrm{M}_{\mathrm{NL}}$ and higher efficiency of $C_{N}$ fertigation is expected with desalinated water, although irrigation with desalinated water did not enhance reduced nitrogen concentration in lettuce and potato organs. In contrast to potato, in lettuce no such clear threshold value of $\mathrm{C}_{\mathrm{N}}$ was obtained. The main reason for this difference is that in lettuce the uptake of nitrogen in low $C_{N}$ values is less efficient than in potato and there was no change in the $\mathrm{N}$ uptake efficiency as a function of $\mathrm{C}_{\mathrm{N}}$.

The linear increase of $\mathrm{C}_{\mathrm{ClL}}$ and $\mathrm{M}_{\mathrm{ClL}}$ as function of $\mathrm{C}_{\mathrm{Cl}}$ that was obtained for both crops in all experiments was expected due to the very low uptake of chloride [13], which does not change considerably the concentration of chloride in the drainage from the irrigation water. Although $\mathrm{C}_{\mathrm{N}}$ had significant effect on $\mathrm{Cl}$ concentration in plant organs, this effect is small relative to the total amount of $\mathrm{Cl}$ applied even in the desalinated water, and therefore it had no significant effect on $\mathrm{C}_{\mathrm{ClL}}$. Thus, the significant effect of $\mathrm{C}_{\mathrm{N}}$ on $\mathrm{M}_{\mathrm{Cl}}$ is due its' effect on $\mathrm{LF}$ discussed above.

\section{Conclusions}

In contrast to the hypothesis of this research, optimal $C_{N}$ in both crops was higher in the desalinated water than in high $\mathrm{C}_{\mathrm{CL}}$ treatments. This result is related to the increase in $\mathrm{N}$ uptake by plants at low $\mathrm{C}_{\mathrm{CL}}$ and with $\mathrm{C}_{\mathrm{N}}$ in the irrigating solution. As expected, $\mathrm{N}$ fertilization suppressed $\mathrm{Cl}$ accumulation in plant tissues without effecting plant biomass production. Drainage of $\mathrm{N}$ and $\mathrm{Cl}$ increased with increasing $\mathrm{C}_{\mathrm{CL}}$ in the irrigating solution and $\mathrm{N}$ fertilization above optimal $\mathrm{C}_{\mathrm{N}}$ resulted in steep rise in downward $\mathrm{N}$ leaching. The overall conclusion is that, as water quality is improved through desalination, higher $\mathrm{N}$ supply is required for high yields with less groundwater pollution by downward leaching of $\mathrm{N}$ and $\mathrm{Cl}$. 
Author Contributions: Conceptualization, A.B.-T. and D.K.; methodology, A.B.-T. and D.K.; validation, A.B.-T. and D.K.; formal analysis, A.B.-T., E.K., and B.K.; investigation, E.K., B.K., I.N., and R.S.; Project administration, I.N., E.K., B.K., and R.S.; resources, D.K. and A.B.-T.; data curation, A.B.-T., E.K., and B.K.; writing-original draft preparation, A.B.-T.; writing-review and editing, A.B.-T. and D.K.; visualization, A.B.-T., E.K., and B.K.; supervision, A.B.-T. and D.K.; funding acquisition, D.K. and A.B.-T. All authors have read and agreed to the published version of the manuscript.

Funding: This research was funded by the Chief Scientist Fund of the Ministry of Agriculture and Rural Development, Israel, grant number 20-13-0013.

Conflicts of Interest: The authors declare no conflict of interest. The funders had no role in the design of the study; in the collection, analyses, or interpretation of data; in the writing of the manuscript; or in the decision to publish the results.

\section{References}

1. Yermiyahu, U.; Tal, A.; Ben-Gal, A.; Bar-Tal, A.; Tarchitzky, J.; Lahav, O. Rethinking desalinated water quality and agriculture. Science 2007, 318, 920-921. [CrossRef]

2. Hanasaki, N.; Yoshikawa, S.; Kakinuma, K.; Kanae, S. A seawater desalination scheme for global hydrological models. Hydrol. Earth Syst. Sci. 2016, 20, 4143-4157. [CrossRef]

3. Stanhill, G.; Kurtzman, D.; Rosa, R. Estimating desalination requirements in semi-arid climates: A Mediterranean case study. Desalination 2015, 355, 118-123. [CrossRef]

4. Israel Water Authority, 2018. Consumption of Potable Water in 2017 (in Hebrew). Available online: http://www.water.gov.il/Hebrew/ProfessionalInfoAndData/Allocation-Consumption-andproduction/20172/shafirim_mavo_2017.pdf (accessed on 16 October 2018).

5. Russo, D.; Kurtzman, D. Using Desalinated Water for Irrigation: Its Effect on Field Scale Water Flow and Contaminant Transport under Cropped Conditions. Water 2019, 11, 687. [CrossRef]

6. Maas, E.V. Crop salt tolerance. In Agricultural Salinity Assessment and Management; Tanji, K.K., Ed.; American Society of Civil Engineers: New York, NY, USA, 1990; pp. 262-304.

7. Maas, E.V.; Hoffman, G.J. Crop salt tolerance-Current assessment. J. Irrig. Drain. Div. ASCE 1977, 103, 115-134.

8. Shanon, M.C.; Grieve, C.M. Tolerance of vegetables crop to salinity. Sci. Hortic. 1999, 78, 5-38. [CrossRef]

9. Sonneveld, C. The salt tolerance of greenhouse crops. Neth. J. Agric. Sci. 1988, 36, 63-73.

10. Grattan, S.R.; Grieve, C.M. Mineral element acquisition and growth response of plants grown in saline environments. Agric. Ecosyst. Environ. 1992, 38, 275-300. [CrossRef]

11. Munns, R. Physiological processes limiting plant growth in saline soil: Some dogmas and hypotheses. Plant Cell Environ. 1993, 16, 15-24. [CrossRef]

12. Volkmar, K.M.; Hu, Y.; Steppuhn, H. Physiological responses of plants to salinity: A review. Can. J. Plant Sci. 1998, 78, 19-27. [CrossRef]

13. Xu, G.; Magen, H.; Tarchitzky, J.; Kafkafi, U. Advances in chloride nutrition of plants. Adv. Agron. 2000, 68, 97-150.

14. Massa, D.; Mattson, N.S.; Lieth, H.J. Effects of saline root environment $(\mathrm{NaCl})$ on nitrate and potassium uptake kinetics for rose plants: A Michaelis-Menten modeling approach. Plant Soil 2009, 318, 101-115. [CrossRef]

15. Feigin, A. Fertilization management of crops irrigated with saline water. Plant Soil 1985, 89, $285-299$. [CrossRef]

16. Kafkafi, U.; Valoras, N.; Letay, J. Chloride interaction with $\mathrm{NO}_{3}$ and phosphate nutrition in tomato. J. Plant Nutr. 1982, 5, 1369-1385. [CrossRef]

17. Feigin, A.; Rylski, I.; Meiri, M.; Shalhevet, J. Response of melon and tomato plants to chloride-nitrate ratio in saline nutrient solutions. J. Plant Nutr. 1987, 10, 1787-1794. [CrossRef]

18. Heuer, B.; Feigin, A. Interactive effects of chloride and nitrate on photosynthesis and related growth parameters in tomatoes. Photosynthetica 1993, 28, 549-554.

19. Frechilla, S.; Lasa, B.; Ibarretxe, L.; Lamsfus, C.; Aparicio-Tejo, P. Pea responses to saline stress is affected by the source of nitrogen nutrition (ammonium or nitrate). Plant Growth Regul. 2001, 35, 171-179. [CrossRef]

20. Flores, P.; Navarro, J.; Carvajal, M.; Cerdá, A.; Martínez, V. Tomato yield and quality as affected by nitrogen source and salinity. Agronomie 2003, 23, 249-256. [CrossRef] 
21. Horchani, F.; R'bia, O.; Hajri, R.; Aschi-Smiti, S. Does the source of nitrogen affect the response of tomato plants to saline stress? Curr. Bot. 2010, 2, 8-14.

22. Bar, Y.; Apelbaum, A.; Kafkafi, U.; Goren, R. Relationship between chloride and nitrate and its effect on growth and mineral composition of avocado and citrus plants. J. Plant Nutr. 1997, 20, 715-731. [CrossRef]

23. Lea-Cox, J.D.; Syvertsen, J.P. Salinity reduces water-use and nitrate-N-use efficiency of Citrus. Ann. Bot. 1993, 72, 47-54. [CrossRef]

24. Rubio, J.S.; García-Sánchez, F.; Rubio, F.; García, A.L.; Martínez, V. The importance of K+ in ameliorating the negative effects of salt stress on the growth of pepper plants. Eur. J. Hortic. Sci. 2010, 75, 33-41.

25. Feigin, A.; Pressman, E.; Imas, P.; Miltau, O. Combined effects of KNO3 and salinity on yield and chemical composition of lettuce and chinese cabbage. Irrig. Sci. 1991, 12, 223-230. [CrossRef]

26. Ben-Gal, A.; Yermiyahu, U.; Cohen, S. Fertilization and blending alternatives for irrigation with desalinated water. J. Environ. Qual. 2009, 38, 529-536. [CrossRef]

27. Jalali, M.; Merrikhpour, H. Effects of poor quality irrigation waters on the nutrient leaching and groundwater quality from sandy soil. Environ. Geol. 2008, 53, 1289-1298. [CrossRef]

28. Feng, Z.Z.; Wang, X.K.; Feng, Z.W. Soil N and salinity leaching after the autumn irrigation and its impact on groundwater in Hetao Irrigation District, China. Agric. Water Manag. 2005, 71, 131-143. [CrossRef]

29. Yasuor, H.; Ben-Gal, A.; Yermiyahu, U.; Beit-Yannai, E.; Cohen, S. Nitrogen Management of Greenhouse Pepper Production: Agronomic, Nutritional, and Environmental Implications. HortScience 2013, 48, 1241-1249. [CrossRef]

30. Levy, Y.; Shapira, R.H.; Chefetz, B.; Kurtzman, D. Modeling nitrate from land surface to wells' perforations under agricultural land: Success, failure, and future scenarios in a Mediterranean case study. Hydrol. Earth Syst. Sci. 2017, 21, 3811-3825. [CrossRef]

31. Spalding, R.F.; Exner, M.E. Occurrence of nitrate in groundwater-A review. J. Environ. Qual. 1993, 22, 392-402. [CrossRef]

32. Erisman, J.W.; Sutton, M.A.; Galloway, J.N.; Klimont, Z.; Winiwarter, W. How a century of ammonia synthesis changed the world. Nat. Geosci. 2008, 1, 636-639. [CrossRef]

33. Elhanany, S. Challenges in preserving the quality of water resources in Israel. In Proceedings of the Conference on Confronting Contamination in Soil and Water, The Israeli Institute for Energy and Environment (in Hebrew), Tel-Aviv, Israel, 28 September 2016.

34. Oyarzun, R.; Arumi, J.; Salgado, L.; Mariño, M. Sensitivity analysis and field testing of the RISK-N model in the Central Valley of Chile. Agric. Water Manag. 2007, 87, 251-260. [CrossRef]

35. Libutti, A.; Monteleone, M. Soil vs. groundwater: The quality dilemma. Managing nitrogen leaching and salinity control under irrigated agriculture in Mediterranean conditions. Agric. Water Manag. 2017, 186, 40-50. [CrossRef]

36. Ben-Gal, A.; Shani, U. A highly conductive drainage extension to control the lower boundary condition of lysimeters. Plant Soil 2002, 239, 9-17. [CrossRef]

37. Shenker, M.; Ben-Gal, A.; Shani, U. Sweet corn response to combined nitrogen and salinity environmental stresses. Plant Soil 2003, 256, 139-147. [CrossRef]

38. Yasuor, H.; Tamir, G.; Stein, A.; Cohen, S.; Bar-Tal, A.; Ben-Gal, A.; Yermiyahu, U. Does water salinity affect pepper plant response to nitrogen fertigation? Agric. Water Manag. 2017, 191, 57-66. [CrossRef]

39. Grattan, S.R.; Grieve, C.M. Salinity-mineral nutrient relations in horticultural crops. Sci. Hortic. 1999, 78, 127-157. [CrossRef]

40. Cordovilla, M.P.; Ocana, A.; Ligero, F.; Lluch, C. Growth and macronutrient contents of faba bean plants: Effects of salinity and nitrate nutrition. J. Plant Nutr. 1995, 18, 1611-1628. [CrossRef]

41. Shalhevet, J. Using water of marginal quality for crop production: Major issues. Agric. Water Manag. 1994, 25, 233-269. [CrossRef]

42. Riberio, A.D.A.; de Lacerda, C.F.; Neves, A.L.R.; de Sousa, C.H.C.; Braz, R.D.S.; de Oliveira, A.C.; Pereira, J.M.G.; Ferreira, J.F.D.S. Use and losses of nitrogen by maize and cotton under salt stress. Arch. Agron. Soil Sci. 2020, 1-14. [CrossRef] 
43. Bernstein, L.; Francois, L.E.; Clark, R.A. Interactive effects of salinity and fertility on yields of grains and vegetables. Agron. J. 1974, 66, 412-421. [CrossRef]

44. Kurtzman, D.; Shapira, R.; Bar-Tal, A.; Fine, P.; Russo, D. Nitrate fluxes to groundwater under citrus orchards in Mediterranean climate observations, calibrated models, simulations and agro-hydrological conclusions. J. Contam. Hydrol. 2013, 151, 93-104. [CrossRef] [PubMed] 